\title{
Performance implications of SA8000 certification
}

\author{
Guido Orzes \\ Free University of Bozen-Bolzano, Bolzano, Italy \\ $\mathrm{Fu}$ Jia \\ Department of Management, University of Bristol, Bristol, UK, and \\ Marco Sartor and Guido Nassimbeni \\ Polytechnic Department of Engineering and Architecture, \\ University of Udine, Udine, Italy \\ UK, and
}

1625

Received 2 December 2015

Revised 14 July 2016

3 February 2017

9 April 2017

Accepted 8 May 2017

\begin{abstract}
Purpose - The purpose of this paper is to shed light on the relationship between the adoption of Social Accountability 8000 (SA8000) - which is considered the most important ethical certification standard - and firm performance, building on agency and contingency theories.

Design/methodology/approach - The authors analyse secondary longitudinal balance sheet data of listed firms employing a rigorous event-study approach and compare SA8000-certified companies to different control groups based on three matching criteria, i.e., industry, size, and pre-certification performance. The authors then study the moderating effects of the cultural features, the country's development level, and the labour intensity on the causal relationship through multiple regression methods.

Findings - The authors find that SA8000 certification positively affects labour productivity and sales performance but has no effect on profitability. Furthermore, the study supports that the relationship between SA8000 and profitability is moderated by two cultural features of the home country of the firms (i.e. power distance and uncertainty avoidance).

Originality/value - This is the first study, which empirically tests the effects of the ethical certification SA8000 on firm performance using a cross-country sample. In addition, the authors contribute to the wider debate on the effects of corporate social responsibility practices on firm performance.
\end{abstract}

Keywords Sustainability, Corporate social responsibility, Event study, Operational performance,

Social accountability, SA8000

Paper type Research paper

\section{Introduction}

The effects of corporate social responsibility (CSR) practices on firm performance have been the subject of a considerable volume of research by business ethics, finance, strategy, and management scholars since the late 1980s (Orlitzky et al., 2003; Crifo et al., 2016; $\mathrm{Wu}$ and Shen, 2013; Foote et al., 2010). These transversal and interdisciplinary topics have recently raised significant interest also among operations and supply chain management scholars (e.g. Crifo et al., 2016; Lo et al., 2013, 2014; Klassen and Vereecke, 2012), since the two aforementioned functions are among the most significantly affected by CSR (Longoni et al., 2014).

After decades of research, the effects of CSR practices on firm performance still remain controversial because of the conflicting results obtained from the empirical studies, i.e., positive relationships (Barnett and Salomon, 2006; Wang and Choi, 2013; Kang and Liu, 2014),

(c) Guido Orzes, Fu Jia, Marco Sartor, Guido Nassimbeni. Published by Emerald Publishing Limited. This article is published under the Creative Commons Attribution (CC BY 4.0) licence. Anyone may reproduce, distribute, translate and create derivative works of this article (for both commercial and non-commercial purposes), subject to full attribution to the original publication and authors. The full terms of this licence may be seen at http://creativecommons.org/licences/by/4.0/legalcode

The authors thank the Department of Innovation, Research and University of the Autonomous Province of Bozen/Bolzano for covering the Open Access publication costs.

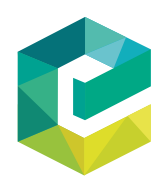

International Journal of Operations \& Production Management Vol. 37 No. 11, 2017 pp. $1625-1653$ Emerald Publishing Limited 0144-3577 DOI 10.1108/IJOPM-12-2015-0730 
IJOPM

37,11

1626

negative relationships (Renneboog et al., 2008; Brammer et al. 2006), neutral relationships (Surroca et al., 2010; Collison et al., 2008), or mixed relationships (Choi et al., 2010; Wang et al., 2008; Park and Lee, 2009).

This paper seeks to empirically analyse the effects of the most widespread ethical certification standard as far as the number of certified firms is concerned (Fuentes-García et al., 2008; Crals and Vereeck, 2005), namely the Social Accountability 8000 (SA8000 hereafter), on performance of certified firms. The SA8000 standard was created by the Social Accountability International (SAI) (formerly known as the Council on Economic Priorities Accreditation Agency) in 1997, based on the conventions of the International Labour Organization, United Nations, and national laws. It focusses on eight prominent areas - child labour, forced or compulsory labour, health and safety in the workplace, freedom of association and the right to bargain collectively, discrimination of employees, disciplinary practices, working hours, and remuneration - and sets for each of them a series of requirements that the company and its upstream supply chain have to respect (Social Accountability International (SAI), 2014). The SA8000 certification is adopted on a voluntary basis but compliance is ensured by certification from a third party, which audits firms on behalf of SAI.

An increasing number of scholars have studied the advantages of SA8000 (e.g. Ciliberti et al., 2009, 2011; Christmann and Taylor, 2006; Stigzelius and Mark-Herbert, 2009) and the obstacles to its adoption (e.g. Fuentes-García et al., 2008; Miles and Munilla, 2004; Rasche, 2010a). However, the relationship between the adoption of the certification and the firm's performance is far from clear due to a lack of rigorous empirical studies and weak theoretical foundations (Sartor et al., 2016).

Previous studies have dealt with the performance impact of other CSR standards/ management systems: ISO 9000 (Corbett et al., 2005; Lo et al., 2014); ISO 14000 (De Jong et al., 2014); OHSAS 18001 (Lo et al., 2014); and ISO 26000 (Valmohammadi, 2014). However, ISO 9000 and ISO 14000 focus on quality management and environmental issues (rather than on ethical issues), respectively. OHSAS 18001 concerns occupational health and safety, which covers only one of the eight issues addressed by the SA8000. Finally, ISO 26000 is an ethical process standard, i.e., a set of CSR guidelines, while SA8000 is an ethical certification standard i.e., compliance is ensured by third-party audits (Gilbert et al., 2010).

To fill abovementioned gaps, this paper addresses the following two research questions:

$R Q 1$. What are the effects of the implementation of SA8000 standard on the performance of listed firms?

RQ2. What are the contingency factors moderating these effects?

In this study, we focus on the firms listed on stock markets for a twofold reason. First, they are more likely to adopt CSR standards/management systems (e.g. Qi et al., 2013) since: stockholders put more pressure on them to be sustainable (Mishra and Suar, 2010); and they need to signal their CSR commitment to stockholders (Khanna et al., 2007; Nishitani, 2010). This also applies to the SA8000 certification: the percentage of certified companies is higher for listed firms than that for all the other firms in a specific country. Let us consider as an example three countries, i.e., Italy, India, and Romania, which account for approximately 65 per cent of the total certified firms. Among the 350 Italian listed firms (The Borsa Italiana SpA., based in Milan), five are SA8000 certified (1.43 per cent); while among the 2.6 million of Italian partnerships and joint-stock companies (Unioncamere, 2015), 1,081 are SA8000 certified (0.042 per cent) (SAI, 2014). Among the approximately 2,600 Indian listed firms (National Stock Exchange of India Limited in Mumbai), 65 are SA8000 certified (2.50 per cent); while among the around one million of Indian partnerships and joint-stock companies (Ministry of Corporate Affairs, 2015), 953 are SA8000 certified (0.093 per cent) (SAI, 2014). 
Among the approximately 83 Romanian listed firms (Bucharest Stock Exchange), three are SA8000 certified (3.62 per cent); while among the around 700,000 Romanian partnerships and joint-stock companies (Eurostat, 2014), 128 are SA8000 certified (0.018 per cent) (SAI, 2014). Second, accurate and cross-country comparable data of listed firms are readily available from public sources because their balance sheets are standardized and subject to disclosure requirements (Takahashi and Nakamura, 2010). This allows us to measure performances through objective data rather than based on self-reported measures.

Drawing from the SA8000 literature and looking through the theoretical lenses of agency and contingency theories, we develop some research hypotheses about the effects of SA8000 on firm performance (i.e. labour productivity, sales growth, and profitability) and the contingency factors that might affect them (e.g. cultural features, country development, labour intensity). We then empirically test these hypotheses through event study and multiple regression methods. A similar approach was adopted by Lo et al. (2014) to study the effects of OHSAS 18001 certification on firm performance.

Our paper contributes to operations and supply chain management theory mainly in three significant ways. First, it is the first study, which empirically tests the effects of the ethical certification SA8000 on firm performance on a cross-country sample. Second, we contribute to the wider debate on the effects of CSR practices on firm performance by supporting the social impact school, which postulates that CSR enhances the firm's reputation among stakeholders and leads to better performance. Third, we shed light for the first time on the moderating effect of national culture on the relationship between CSR practices and firm performance.

Our study might also help managers to understand the potential value of SA8000 certification and the factors potentially affecting its effectiveness and to take more informed decisions about the implementation of CSR certification standards in general.

\section{Literature review}

Many authors have studied the relationship between CSR practices and firm performances since the late 1980s obtaining varying outcomes: a positive relationship (e.g. Barnett and Salomon, 2006; Shen and Chang, 2009; Wang and Choi, 2013; Kang and Liu, 2014; Tate et al., 2010; Klassen and Vereecke, 2012; Carter and Rogers, 2008), a negative relationship (e.g. Renneboog et al., 2008; Brammer et al., 2006), a neutral relationship (e.g. Surroca et al., 2010; Collison et al., 2008), and a mixed relationship (e.g. Choi et al., 2010; Wang et al., 2008; Park and Lee, 2009; Godfrey et al., 2009). For a detailed review of these studies, see Margolis and Walsh (2003), Orlitzky et al. (2003), and Carroll and Shabana (2010) among others. The first possible reasons for the varying/conflicting results of the studies may be related to their focus on different CSR practices/initiatives, such as the ISO 14001 certification, the OHSAS 18001 certification, the ISO 26000 standard, the company's ethical codes of conducts, and other specific social/environmental practices measured through self-reported survey measures or external evaluations (e.g. Dow Jones sustainability index, Domini 400 social index) (see Orlitzky et al., 2003). Other possible motivations may concern instead the different performance measurements considered, such as sales, cost-efficiency, profitability, and shareholder value. The aforementioned varying/conflicting results might also be traced back to two conflicting schools of thought in management theory (Shen and Chang, 2009; Tang et al., 2012): the social impact school, which argues that CSR enhances the firm's reputation among stakeholders and leads to better performances (e.g. Preston and O'Bannon, 1997; Berman et al., 1999; Carmeli et al., 2007) and the shift of focus school, which claims instead that CSR increases firm's costs and deflects the focus from the maximisation of stockholders' value (Brammer and Millington, 2008; Becchetti et al., 2007).

Considering the focus of this paper and the specificities of the SA8000 certification in comparison with other CSR practices/initiatives, we conducted a systematic literature review 
IJOPM

37,11

1628

on the effects of SA8000 certification. We performed a keyword search in the main electronic databases (Thomson Reuters Web of Science, Scopus, and Academic Search Premier EBSCO), using the keywords "SA8000", "SA 8000", and "Social Accountability 8,000". We then screened the full texts of the 318 identified contributions and excluded those which only cited the SA8000 certification without any analysis/discussion (268 papers) and those that do not provide any information on the impact (or potential impact) of the SA8000 certification adoption on at least one firm performance measure, and not even on a comparative basis (18 papers). The second group of excluded papers deals with the diffusion processes of the certification (e.g. Llach et al., 2015) or the comparison between the implementation of SA8000 and the implementation of other standards/management systems (e.g. Ciliberti et al., 2008), which is not relevant for the purpose of this study. By means of this search strategy, we identified 32 relevant papers dealing with the effects of SA8000 certification, which were published from 2002 to 2015 in business ethics/sustainability journals (21 papers, nine of which were published in the Journal of Business Ethics), operations and supply chain management journals (three papers), international business journals (one paper), marketing journals (one paper), and general management journals (six papers).

The papers are summarised in Table I, which reports the hypothesised or tested effects of SA8000; the methodological approaches adopted to highlight/postulate these effects; and the underpinning theoretical frameworks (if any). The effects are classified according to their nature (i.e. positive vs negative effects) and functional area (i.e. operational, market, innovation, and other effects).

Before discussing in detail the hypothesised/tested effects, it is worthwhile considering the methodological approaches adopted by the reviewed studies and their theoretical foundations. In total, 19 contributions (59.5 per cent) are conceptual (theoretical framework development based on literature review and anecdotal evidence), ten (31.3 per cent) are based on case studies, two (6.1 per cent) adopted a survey method, and one (3.1 per cent) contribution is based on the experimental auction. Focussing on the two papers that seek to empirically test some effects of the SA8000 certification through survey method, we notice that Battaglia et al. (2014) is based on a sample of 213 fashion (small and medium) enterprises located in Italy and France and considers all ethical certifications together (e.g. SA8000, Fair Trade, and Trans Fair) without separating the effects of SA8000 from the other certifications. In addition, it relies on self-reported performance data. The hypotheses tested by this study (see Table I) should therefore be further verified with a specific reference to SA8000 certification, possibly adopting a more heterogeneous sample for firm size and country of location and also considering objective quantitative performance data (such as balance sheet data). The other paper (Merli et al., 2015) relies on the data of 649 Italian SA8000-certified firms and is based on self-reported performance data. While Italy is the country with the highest number of certified firms, results of this study should be verified by a geographically dispersed sample, possibly also considering objective quantitative performance data. In summary, a need exists for large-scale quantitative studies empirically testing/verifying the effects of SA8000 certification identified by the extant literature.

As far as the theoretical foundations of reviewed studies are concerned, only five contributions (16 per cent) are grounded on mainstream theories. Starting from two predictions based on the transaction cost economics (TCE) (Coase, 1937; Williamson, 1975), i.e., monitoring reduces customer-supplier information asymmetries and opportunistic behaviours (Balakrishnan and Koza, 1993) and sanctions reduce the likelihood of opportunistic behaviours (Williamson, 1996), Christmann and Taylor (2006) analyse the level of quality of implementation (symbolic vs substantive) of international certifiable standards (including SA8000). Building on agency theory, Ciliberti et al. (2011) show that the adoption of codes of conduct, in particular of third-party certifications such as SA8000, 


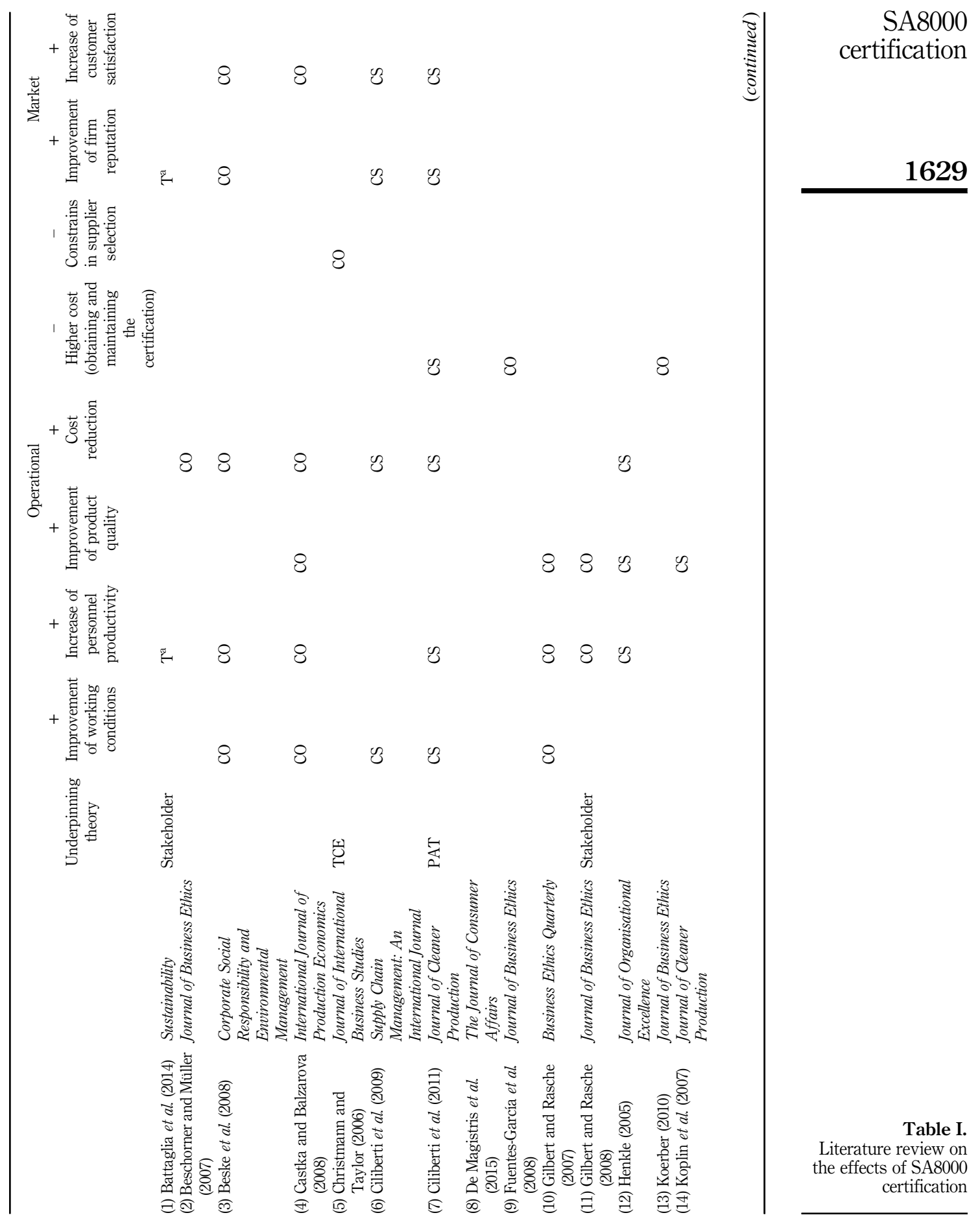




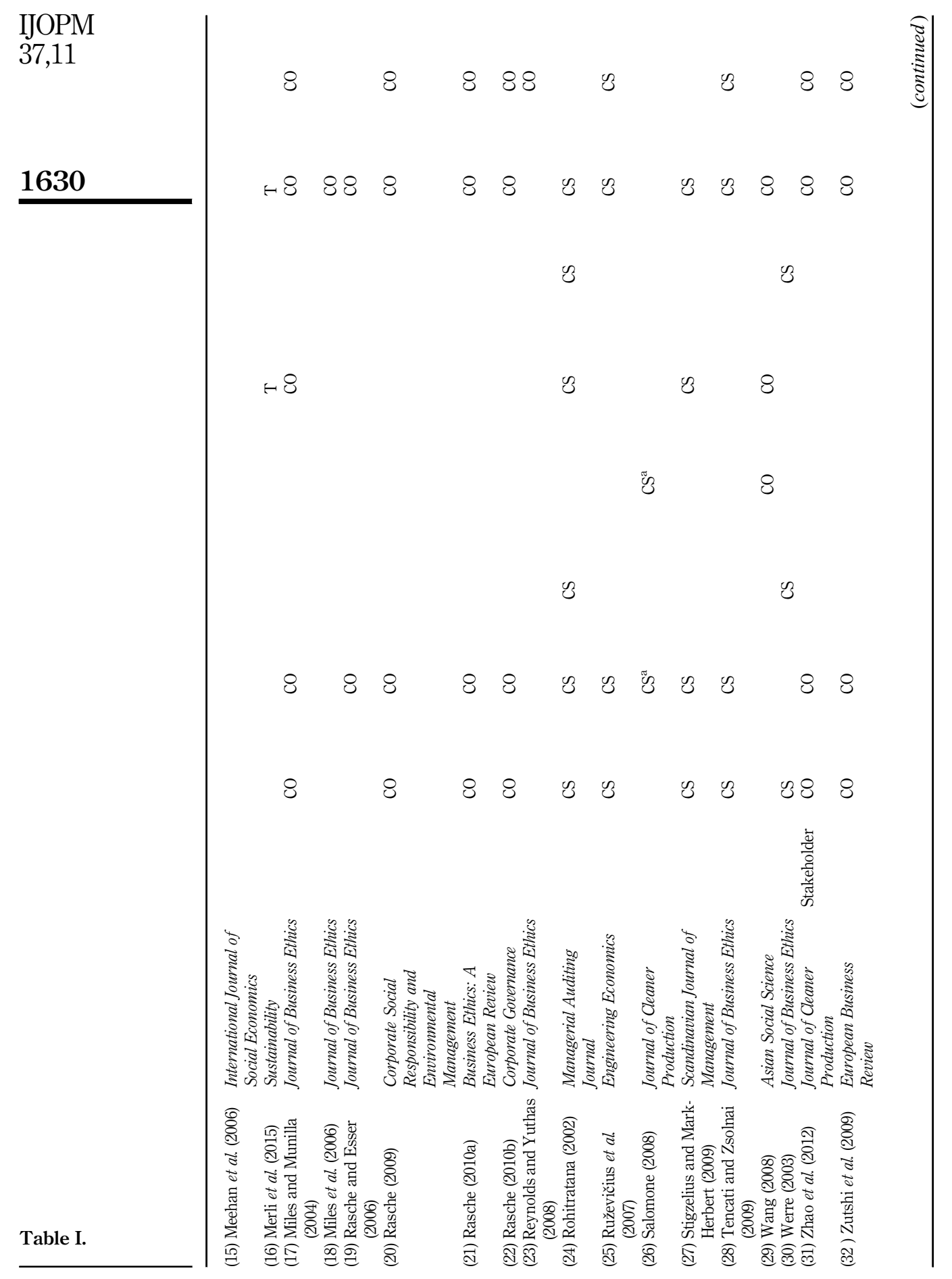




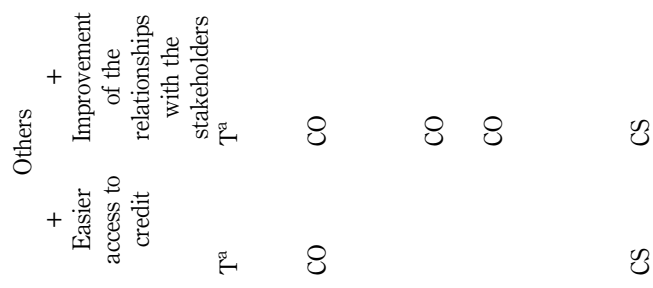

ฐ $\begin{array}{r}\text { SA8000 } \\ \text { certification }\end{array}$

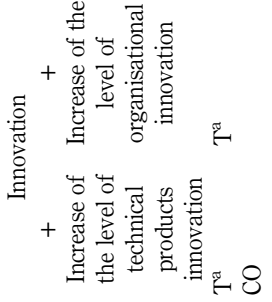

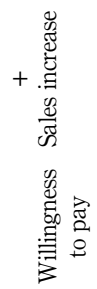

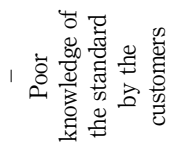

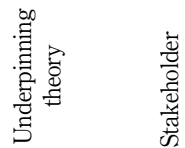

8

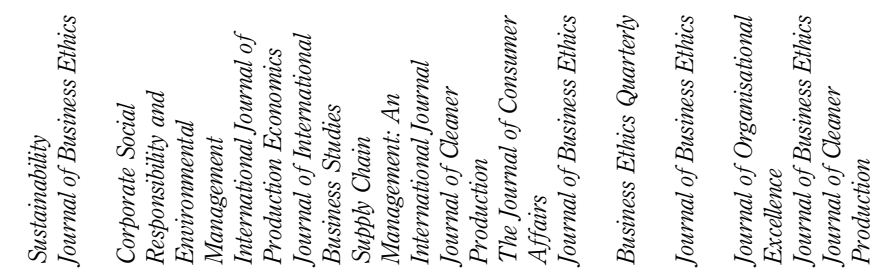

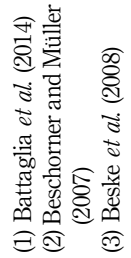
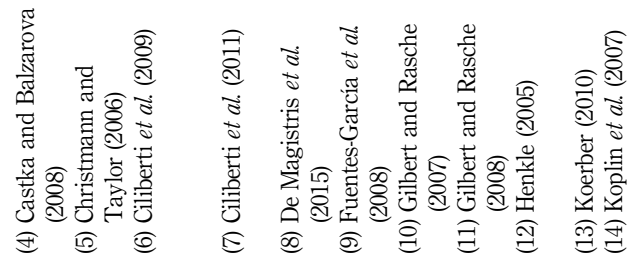

Table I. 


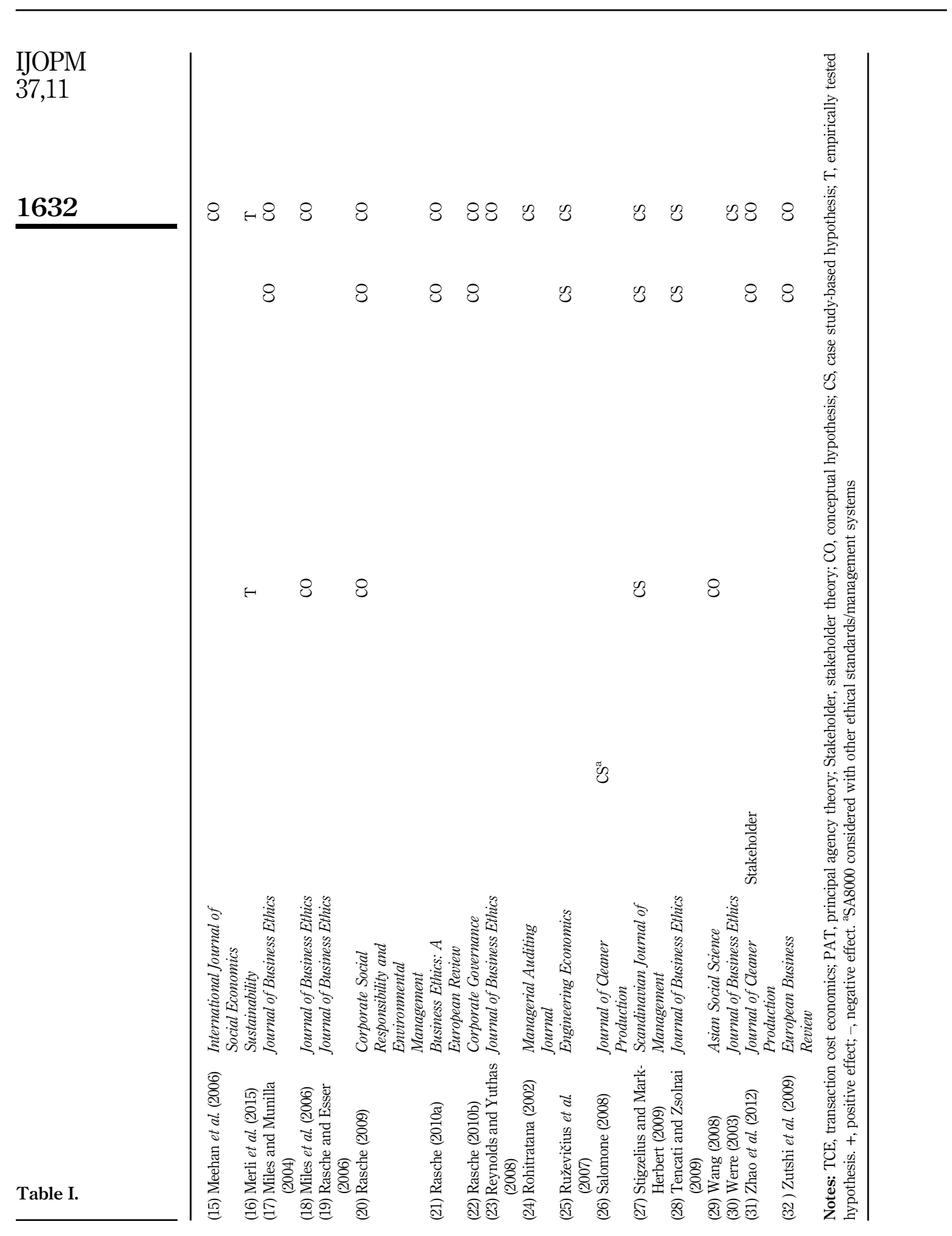


reduces the information asymmetry between the firm (principal) and its partners (agents). This could attenuate two key problems in agency relationships, i.e., moral hazard and adverse selection (mainly caused by information asymmetry). Gilbert and Rasche (2007) discuss some opportunities and problems created by standardized ethics initiatives (e.g. SA 8000) from the perspective of the stakeholder theory (Freeman, 1984; Donaldson and Preston, 1995). Furthermore, they highlight that these standardized initiatives: provide guidance on how to take into account stakeholder interests but the advices given on the communication with stakeholders are too unspecific (descriptive stakeholder theory); allow firms in general to reduce long-term costs and increase productivity but might create a variety of costs that can be harmful (especially for small and medium enterprises) (instrumental stakeholder theory); and provide a communicative-rational moral point of view but the design of discourses to develop norms is often insufficient (normative stakeholder theory). Zhao et al. (2012) shed light on the stakeholders of various CSR initiatives (including SA8000), e.g., employees, shareholders, creditors, suppliers, environment and resources agency, local communities, and government, and seek to propose CSR indicators based on stakeholder theory. Finally, Battaglia et al. (2014) measure the level of adoption of CSR practices based on stakeholder theory by focusing on four areas of responsibility (i.e. human resources, market, community and environmental outcomes) and estimated the consequent performance impact.

Several authors (e.g. Rasche, 2009; Ruževičius and Serafinas, 2007; Stigzelius and Mark-Herbert, 2009) argue that the adoption of SA8000 certification leads to improvement of working conditions. This effect might sound quite tautological to readers, as it is in fact the main goal of the certification. However, it allows us to introduce a set of further effects hypothesised by the reviewed studies. Henkle (2005) and Stigzelius and Mark-Herbert (2009) highlight, for instance, that workers of SA8000-certified firms feel more protected and involved in the achievement of the strategic goals and this tends to reduce absenteeism and staff turnover. Other authors hypothesise (e.g. Fuentes-García et al., 2008; Miles and Munilla, 2004; Rohitratana, 2002; Wang, 2008) and support the argument that SA8000 certification contributes to increasing the firm's ability to attract a skilled workforce (Merli et al., 2015). These benefits of the certification together with a generally higher enthusiasm of the employees led many authors to hypothesise that SA8000 certification increases personnel productivity (e.g. Castka and Balzarova, 2008; Ciliberti et al., 2011; Stigzelius and Mark-Herbert, 2009). Other authors postulate that SA8000 also leads to improvement of product quality (e.g. Castka and Balzarova, 2008; Henkle, 2005; Koplin et al., 2007).

Another operational effect of the certification hypothesised by many authors is cost reduction (e.g. Castka and Balzarova, 2008; Henkle, 2005; Wang, 2008). Rohitratana (2002) and Salomone (2008) notice for instance that changes made to align business processes to SA8000 requirements lead to the increase in their efficiency. The cost reduction effect is however a debated issue. Many authors in fact, warned against the high costs of obtaining and maintaining the certification (e.g. Ciliberti et al., 2011; Miles and Munilla, 2004; Rohitratana, 2002). The activities performed to comply with the SA8000 requirements (such as modification of the business processes, additional compensation for overtime, and data collection and management) increase costs. The fees charged by certification bodies, third-party auditors (and sometimes the external consultants involved) incur further costs. In addition, SA8000 imposes constraints on supplier selection (Christmann and Taylor, 2006; Rohitratana, 2002; Werre, 2003). Certified companies must in fact persuade their suppliers to comply with the SA8000 requirements, limiting selection of potential suppliers only to those that are willing and able to meet these requirements. This entails additional costs for searching and the need of paying a premium.

Christmann and Taylor (2006) highlight that the quality of standard implementation differs across certified firms: some firms pursue only a symbolic implementation in which 
IJOPM

37,11

1634

the certified management system is not used in their daily operations, while others pursue a substantive implementation in which standard requirements are embedded in their daily routines. Despite the fact that no study has faced this issue, most of the aforementioned operational effects (e.g. increases in personnel productivity, improvement of product quality, and cost reduction) might vary significantly according to the type of implementation truly performed.

The attention to workers' rights, the defence of child labour, and in general the attention to ethical issues were hypothesised to improve firm reputation (e.g. Miles and Munilla, 2004; Rohitratana, 2002; Zutshi et al., 2009) and to increase customer satisfaction (e.g. Beske et al., 2008; Ciliberti et al., 2009; Zhao et al., 2012). The first abovementioned effect was also supported by Battaglia et al. (2014) and Merli et al. (2015). De Magistris et al. (2015) empirically confirm through an experimental auction in southern Italy involving 88 consumers that the SA8000 certification increased the customers' willingness to pay canned tuna fish. Fuentes-García et al. (2008) and Salomone (2008) argue however that due to the poor knowledge of the standard owned by the customers, companies should invest significant resources in the promotion of their commitment to this initiative.

Some authors then argue that SA8000 leads to sales increase (Merli et al., 2015; Miles et al., 2006; Stigzelius and Mark-Herbert, 2009). On the one hand, the certification allows companies to attract new customers and retain the existing ones (see the previous paragraph). On the other hand, it allows firms to charge a premium price by targeting the "ethical consumers".

A few studies claim that the SA8000 certification has a positive effect on technical products and on organisational innovation (Battaglia et al., 2014; Beschorner and Müller, 2007; Gilbert and Rasche, 2007). Certified firms can in fact conduct co-design and co-development activities with the stakeholders who have a similar ethical sensibility (Battaglia et al., 2014). Changes performed to align processes and procedures to SA8000 requirements might also lead to organisational innovations such as the adoption of new organisational structures (Beschorner and Müller, 2007).

A further effect of SA8000 certification postulated by many authors is the easier access to bank credit (e.g. Beske et al., 2008; Ruževičius and Serafinas, 2007; Zutshi et al., 2009). Compliance with SA8000 requirements might in fact facilitate relationships with banks and investors as well as with monitoring authorities (e.g. public welfare, assistance bodies, and control agencies for safety). This effect is however not supported by Merli et al.'s (2015) survey results.

Finally, several studies argue that SA8000 leads to the improvement of the relationship with the stakeholders (e.g. Battaglia et al., 2014; Beschorner and Müller, 2007; Miles and Munilla, 2004). This is a multi-faceted effect encompassing several of the aforementioned benefits such as better relationships with employees (increase of personnel productivity), better relationships with customers (increased customer satisfaction/increase of sales), and better relationships with banks and investors (easier access to credit).

Despite the significant attention devoted to the effects of the SA8000 certification, no previous study has analysed or discussed the factors that might moderate the relationship between the adoption of the SA8000 certification and the firm performances. These moderating factors have been studied for the relationship between other CSR practices and firm performance. Lee, Seo and Sharma (2013) and Lee, Singal and Kang (2013) find a positive moderating effect of oil prices and economic conditions (recession vs non-recession) on the relationship between operations-related CSR activities (i.e. employee relations, product quality, and corporate governance) and firm performance. Youn et al. (2015) show that firm size moderates the positive effect of CSR on corporate financial performance in the context of US restaurants. A negative moderating effect of firm 
size is instead found by Hou et al. (2016) in their meta-analysis of 28 empirical studies. Hou et al. (2016) also identify two further moderators: organisational form (CSR performance impact is higher for private firms than for public firms) and economic development of the country (higher impact in developing economies). Instead, they find no moderating effect of the industry. Fernández Sánchez et al. (2015) show that the relationship between CSR and firm performances is stronger in a turbulent environment (i.e. unstable and/or unpredictable). Finally, Zhu et al. (2014) supported that ethical leadership moderates the indirect (mediated) effect of CSR on firm performance via firm reputation. There are two studies focussed on the factors moderating the relationship between the adoption of specific CSR standards (ISO 9000, OHSAS 18001) and the firm performances. Lo et al. (2013) find that the performance impact of ISO 9000 is moderated by firm technology intensity (negatively), firm labour productivity (negatively), firm labour intensity (positively), industry efficiency (negatively), industry concentration (negatively), industry sales growth (positively), and industry ISO 9000 adoption level (negatively). Lo et al. (2014) show that the performance impact of OHSAS 18001 is positively moderated by operational complexity (R\&D and labour intensity) and operational coupling (increased inventory volatility and decreased inventory level).

In sum, a significant number of studies have dealt with the effects of the SA8000 certification. This literature is however mainly conceptual (60 per cent) and case-based (33 per cent) and rather descriptive/a-theoretic (see Table I). In addition, although a set of factors moderating the relationship between CSR practices or CSR standards and firm performances have been identified in the literature, to the best of our knowledge, none has proposed or tested these factors with reference to the SA8000 performance implications. Finally, despite the significant attention of operations management scholars to the moderating effect of cultural features on the practice-performance relationship - see Wiengarten et al. (2015) on lean practices among others - none focussed on this moderator for CSR practices/standards performance implications. A prominent need therefore exists to conduct quantitative empirical analyses on the effects of SA8000 certification and the factors that may moderate these effects.

\section{Research framework and hypotheses development}

In this section, we develop a set of research hypotheses related to the effects of SA8000 on firm performances and summarise them through a research framework. These hypotheses are developed based on a combination of: previous literature and its research gaps (see Table I) data available in our study (mainly balance sheet data).

The key aim of SA8000 standard is to "advance the human rights of workers around the world" (SAI, 2014). A number of previous studies have argued conceptually, anecdotally, or empirically (based on case studies) that the SA8000 certification leads to the improvement of working environment, the enhancement of workers-managers communication, and the increased satisfaction of employees (e.g. Miles and Munilla, 2004; Ciliberti et al., 2011). Some authors have then hypothesised that these benefits positively affect the firm's ability to motivate, retain, and recruit smart human resources, which in turn increase labour productivity (e.g. Stigzelius and Mark-Herbert, 2009; Tencati and Zsolnai, 2009). From an agency theory perspective (Jensen and Meckling, 1976), the aforementioned benefits may lead to a reduction in the information asymmetry between the (top) management (principal) and the employees (agents) which mitigates the moral hazard and adverse selection problems. We therefore postulate that:

H1. There is a positive relationship between SA8000 adoption and labour productivity.

Previous studies argued that SA8000 implementation might lead to improvement in corporate image and brand value (e.g. Koerber, 2010; Miles and Munilla, 2004; Stigzelius and 
IJOPM

37,11

1636

Mark-Herbert, 2009). Specific market segments (sometimes labelled as "ethical consumers") are particularly sensible to ethical issues and might be willing to pay premium prices for products from SA8000-certified companies (Annunziata et al., 2011). In addition, certified companies are expected to experience a more efficient development of new products (e.g. Beschorner and Müller, 2007; Gilbert and Rasche, 2007; Ruževičius and Serafinas, 2007). The aforementioned SA8000 benefits lead many scholars to hypothesise that SA8000 implementation leads to market expansion (e.g. Christmann and Taylor, 2006; Miles and Munilla, 2004; Salomone, 2008; Stigzelius and Mark-Herbert, 2009). SA8000 may also act as a social legitimacy signal to major customers (Suchman, 1995), this way allowing firms to meet customers' CSR requirements and improve sales performance. Similarly, applying agency theory (Jensen and Meckling, 1976) to the relationships between the firm and its customers, we might argue that SA8000 adoption can represent a credible signal to the customers of the firm's commitment to CSR practices, which help improve sales performance of firms. We therefore propose that:

H2. There is a positive relationship between SA8000 adoption and sales performance.

No previous studies hypothesise or analyse a possible link between SA8000 adoption and firm profitability. Several more specific SA8000 effects hypothesised by previous studies can in turn positively affect firm profitability: the increase of personnel productivity, the improvement of product quality, cost reduction, the increase of the level of technical innovation, the improvement of firm reputation, the increase of customer satisfaction, and the sales increase (e.g. Beske et al., 2008; Castka and Balzarova, 2008; Merli et al., 2015; Ciliberti et al., 2011; Stigzelius and Mark-Herbert, 2009). However, the obtainment and maintenance of the certification lead to higher costs (e.g. Ciliberti et al., 2011; Stigzelius and Mark-Herbert, 2009; Rohitratana, 2002). We therefore hypothesise that:

H3. There is a positive relationship between SA8000 adoption and profitability.

Contingency theory postulates that there is no best way to organise or manage a firm: the proper strategies and actions depend upon a set of internal and external factors (e.g. Donaldson, 2001). This theoretical framework might therefore be applied to the performance effects of SA8000, leading us to hypothesise that the relationship between the certification and firm performance is moderated by some internal and external factors. These possible moderating factors have been never studied so far with reference to SA8000 certification. Some previous studies have however focussed on the relationship between the adoption of other CSR practices/standards and firm performances, highlighting a set of moderating factors including: economic conditions, economic environment, or the economic development of the country (Lee, Seo and Sharma, 2013; Lee, Singal and Kang, 2013; Hou et al., 2016; Fernández Sánchez et al., 2015), firm technology and labour intensity (Lo et al., 2013, 2014), firm size (Youn et al., 2015; Hou et al., 2016), and industry (Lo et al., 2013). We consider the moderating effects of some of the most important aforementioned variables (e.g. economic development of the country and labour intensity) on the SA8000 adoption and firm performance relationship. The others (e.g. firm size and industry) are used as control variables in our study.

The improvement in working conditions required for developing countries' companies to obtain SA8000 certification is higher since the initial working conditions in these countries are generally worse off (Sartor et al., 2016). This may lead to different effects of the certification according to the level of development of the country of origin. In their meta-analysis, Hou et al. (2016) find for instance that CSR practices have higher performance impact in developing economies. We might therefore expect that:

H4a. The effect of SA8000 adoption on profitability is moderated by the level of development in the country of origin. 
Any CSR initiative or certification is grounded on a specific concept of "social good". This may depend on cultural values and often differs dramatically between nations, cultures, and market segments (Miles and Munilla, 2004). Cultural perspective highlights that different social systems, ways of life, and people's worldviews exist and they affect the management of organisations (e.g. Hofstede, 1980). While previous studies have analysed the moderating effects of cultural features on the relationship between OM practices (such as lean production) and firm performance (e.g. Wiengarten et al., 2015). However, quite surprisingly, no study has investigated the role of culture on the relationship between CSR practices and firm performances. We acknowledge the importance of cultural issues for SA8000 certification and hypothesise that:

$H 4 b$. The effect of SA8000 adoption on profitability is moderated by the country of origin's cultural features.

When labour intensity increases, firm operations become more variable and complex (Swink and Jacobs, 2012; Prater et al., 2001), production systems become more dependent on people, and the need for a formalized process to manage quality becomes increasingly important (Lo et al., 2014). On the contrary, for a low labour-intensive firm there is less room for further improvement in the quality management system due to the higher level of automation (Park et al., 2010; Hendricks and Singhal, 2008) (Figure 1). We therefore hypothesise that:

H5. The effect of SA8000 adoption on profitability is positively moderated by the labour intensity of the company.

\section{Methodology}

This study is based on secondary data from the Standard and Poor Capital IQ's Compustat Global data set, which includes balance sheet information from 1989 to 2013 of more than 32,000 listed firms located in 82 countries and representing more than 90 per cent of the Asian market capitalisation and more than 95 per cent of the European one. Combining Compustat Global data set with the official comprehensive list of certified companies (Social Accountability Accreditation Services (SAAS), 2014), we identified a sample of 101 SA8000-certified firms.

These sampled SA8000-certified companies were spread across a wide spectrum of industries (e.g. mining, construction, food, textile, apparel, glass, electronic and electrical equipment, transportation, trade, hotels, and business services), with a prevalence of manufacturing activities (Standard Industrial Classification (SIC) codes 2000-3999) (see Table II).

As far as country distribution is concerned, around 60 per cent of the sampled certified companies are located in India, followed by Taiwan (around 11 per cent), Pakistan

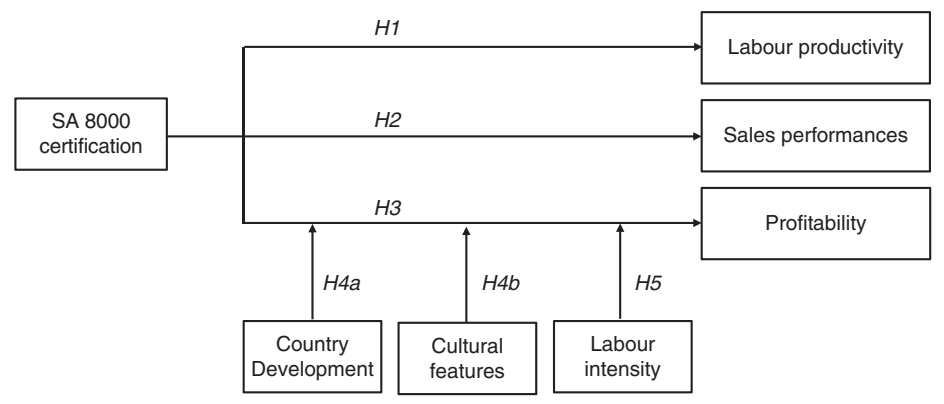

Figure 1. Research framework 
IJOPM

37,11

1638
Sector

Mining

Construction

Manufacturing

Food and kindred products

Tobacco products

Textile mill products

Apparel and other fabrics finished products

Paper and allied products

Chemicals and allied Products

Rubber and plastic products

Leather and leather products

Stone, clay, and glass

Primary metal industries

Electronic and electrical equipment

Transportation equipment

Transportation and public utilities

Wholesale and retail trade

Table II.

Breakdown of sample certified firms by industries
Services (e.g. hotels, business services, recreation services)

Others (non-classifiable)

Total

\section{SIC Code}

Number of companies

$\begin{array}{cc}10 & 1 \\ 16 & 3 \\ 20-39 & \end{array}$

1

20-39

4

23

10

$\begin{array}{cr} & 10 \\ & 2 \\ & 7 \\ & 2 \\ & 3 \\ & 10 \\ & 8 \\ & 12 \\ 40-49 & 2 \\ 50-51 & 5 \\ 70-79 & 3 \\ 99 & 3 \\ & 2 \\ & 101\end{array}$

(around 6 per cent), Italy (around 5 per cent), Vietnam (around 3 per cent), and Romania (around 3 per cent) among others (see Table III).

Finally, the sampled certified companies obtained the certification from 2001 to 2014, with the higher frequencies in the period 2007-2013.

The analysed sample - and the population of interest for our study, which consists of listed SA8000-certified companies - differs from the wider population of SA8000-certified companies for some features such as: firm sizes (while 67 per cent of SA8000-certified

\begin{tabular}{|c|c|c|c|c|c|c|}
\hline & \multicolumn{2}{|c|}{ All certified companies (SAI list) } & \multicolumn{2}{|c|}{ Compustat global database } & \multicolumn{2}{|c|}{ Sampled certified companies } \\
\hline & Number & Percentage & Number & Percentage & Number & Percentage \\
\hline Italy & 1,107 & 32.56 & 348 & 1.09 & 5 & 4.95 \\
\hline India & 884 & 26.00 & 2,654 & 8.28 & 65 & 64.36 \\
\hline China & 608 & 17.88 & 2,579 & 8.04 & & \\
\hline Romania & 128 & 3.77 & 68 & 0.21 & 3 & 2.97 \\
\hline Bulgaria & 96 & 2.82 & 24 & 0.08 & & \\
\hline Vietnam & 82 & 2.41 & 275 & 0.86 & 3 & 2.97 \\
\hline Brazil & 72 & 2.12 & 399 & 1.24 & 1 & 0.99 \\
\hline Pakistan & 64 & 1.88 & 274 & 0.85 & 6 & 5.94 \\
\hline Portugal & 39 & 1.15 & 77 & 0.24 & & \\
\hline Spain & 34 & 1.00 & 179 & 0.56 & & \\
\hline Taiwan & 32 & 0.94 & 1,796 & 5.60 & 11 & 10.89 \\
\hline Greece & 24 & 0.71 & 244 & 0.76 & & \\
\hline Lithuania & 24 & 0.71 & 37 & 0.12 & & \\
\hline Sri Lanka & 20 & 0.59 & 190 & 0.59 & 2 & 1.98 \\
\hline Germany & 12 & 0.35 & 1,026 & 3.20 & & \\
\hline Israel & 11 & 0.32 & 348 & 1.09 & 1 & 0.99 \\
\hline UK & 11 & 0.32 & 2,733 & 8.52 & & \\
\hline Turkey & 8 & 0.24 & 234 & 0.73 & 1 & 0.99 \\
\hline Other countries & 55 & 4.24 & 18,585 & 57.98 & 3 & 2.97 \\
\hline Total & 3,311 & 100.00 & 32,070 & 100.00 & 101 & 100.00 \\
\hline
\end{tabular}

Table III.

Breakdown of certified firms by countries
11 certified companies (SAI list) Compustat global database Sampled certified companies 
companies reported in the SAAS (2014) list are small and medium enterprises, most of the SA8000-certified listed companies are large firms) and countries of origin (while most of SA8000-certified companies reported in the SAAS (2014) list are located in Italy, India, and China, the SA8000-certified listed companies are mainly located in India, Taiwan, Pakistan, and Italy - see Table III). Caution is therefore required to generalise our results to the wider population of SA8000-certified companies. Several previous studies about other certifications such as ISO 9000, ISO 14001, and OHSAS 18001 (e.g. Barber and Lyon, 1996; Corbett et al., 2005; De Jong et al., 2014; Lo et al., 2013, 2014) have however focused on firms listed on stock markets for three main reasons: they are more likely to adopt these certifications; they have specific resources, strategies, issues, and implementation paths that call for a separate analysis; and reliable cross-country accounting data are more readily available for these companies.

We employed the event-study methodology to detect abnormal performance between the 101 SA8000-certified firms and a wide set of control firms, this way testing $H 1, H 2$, and $H 3$. A similar approach was adopted by Barber and Lyon (1996), De Jong et al. (2014), and Lo et al. (2014) to study the effects of ISO 9000, ISO 14001, and OHSAS 18001 on firm performance. The event period was defined as the year in which the certification was received (year $t$ ) and the year immediately preceding certification (year $t-1$ ) since the implementation process lasts on average approximately 18 months (SAI, 2014). The year preceding the event period $(t-2)$ was considered the base year and used for determining the control firm sample. Year $t-3$ was taken into account to tackle the endogeneity issue.

The following performance measures were adopted: the ratio of operating income to number of employees for labour productivity, the relative sales growth, defined by $\left(\right.$ SALES $_{t}-$ SALES $\left._{t-1}\right) /$ SALES $_{t-1}$ (Corbett et al., 2005) for sales performance, the return on assets (ROA) for profitability. For each certified firm, a portfolio of non-SA8000-certified control firms was created adopting the following criteria: the same two-digit SIC code; 50-200 per cent of firms' total assets; and 90-110 per cent per cent of the considered performance (i.e. labour productivity, sales growth, or ROA) in year $t-2$ (if no firm was matched, the first criterion was relaxed to the same one-digit SIC code and then removed). On average, each sampled company matched with eight control firms for each performance and the 64 per cent of them matched with three or more control firms[1]. Table IV provides some descriptive analyses for the 101 certified firms.

We then estimated the abnormal change in performance of the sampled firms in comparison with the control firms as follows:

$$
\begin{gathered}
A P_{(t+b)}=P S_{(t+b)}-E P_{(t+b)} \\
E P_{(t+b)}=P S_{(t+a)}+\left(P C_{(t+b)}-P C_{(t+a)}\right)
\end{gathered}
$$

where AP is the abnormal performance, $\mathrm{EP}$ is the expected performance, $\mathrm{PS}$ is the actual performance of the sampled firms, $\mathrm{PC}$ is the median performance of control firms, $t$ is the

\begin{tabular}{lcccccr}
\hline & Min. & Max. & Median & Mean & SD & \\
\cline { 1 - 4 } Certified firms & & & & & & \\
Number of employees & 65 & 121,295 & 4,708 & 10,009 & 17,559 & \\
Total assets (M\$) & 3.15 & $109,251.70$ & 206.66 & $1,862.38$ & $10,910.55$ & Table IV. \\
Net sales (M\$) & 1.13 & $177,739.1$ & 146.28 & $2,693.04$ & $18,026.59$ & Descriptive analysis \\
Labour productivity (K\$/employee) & -5.74 & 91.61 & 4.43 & 11.61 & 19.58 & for certified firms \\
Sales performance (\%) & -35.84 & 151.26 & 8.90 & 17.48 & 29.22 & (1999-2014) \\
Profitability (\%) & -3.47 & 13.06 & 0.12 & 0.54 & 2.03 & \\
\hline
\end{tabular}


IJOPM

37,11

1640

SA8000 certification year, $a$ is the starting year of comparison $(-3,-2,-1,0,1), b$ is the ending year of comparison $(-2,-1,0,1,2)$.

Finally, we tested whether the abnormal performance differed significantly from zero through $t$-test, Wilcoxon-signed rank (WSR) test and the sign test, applying the Benjamini and Hochberg's (1995) false discovery rate methodology to take into account the multipletesting problem.

The ordinary least squares (OLS) regression methodology is applied to study the moderating effect of contingency factors on the relationship between SA8000 adoption and profitability, testing $H 4 a, H 4 b$, and $H 5$.

Two main approaches have been used so far to measure the level of development of the countries. The first approach focusses on the economic performances of the countries. The classification of the International Monetary Fund considers for instance: the per capita income level, the export diversification, and the degree of integration into the global financial system (International Monetary Fund, 2016). The second approach emphasises instead people and their capabilities. The Human Development Index (HDI) measures, for instance, the average achievements in the following dimensions: long and healthy life, knowledge, and decent standard of living (United Nations Development Programme, 2014). Considering the focus of SA8000 certification, we believe that the second approach was more suitable and decided to use the 2013 HDI (United Nations Development Programme, 2014) for measuring the level of development of the country of origin. We acknowledge anyway that a good overlapping between the two approaches exists.

Two main rigorous measurement systems for national culture have been proposed so far: Hofstede (1980) and GLOBE (House et al., 2004). Hofstede (1980) highlights and measures four dimensions of country culture: power distance (i.e. the degree to which the less powerful members accept that power is distributed unequally), individualism (i.e. preference for a social framework in which individuals take care of only themselves and their own families), masculinity (i.e. preference for achievement, heroism, assertiveness and material rewards), uncertainty avoidance (i.e. the degree to which the members of a society feel uncomfortable with uncertainty and ambiguity). He subsequently adds two further dimensions: long-term orientation (i.e. openness towards societal changes) and indulgence (i.e. allowing free gratification of human drives related to enjoying life and having fun) (Hofstede et al., 2010). Hofstede's country scores have been considered as the major contribution in the field (Smith, 1992) and have been extensively adopted in OM studies, see Wiengarten et al. (2015), Jia and Lamming (2013), and Cagliano et al. (2011) among others. Similarly, the GLOBE project has proposed a model consisting of nine cultural dimensions considered, partially overlapping Hofstede's dimensions: performance orientation; future orientation; assertiveness; uncertainty avoidance; power distance; collectivism; family collectivism; gender differentiation; and humane orientation. In our study, we acknowledge the similarities in the two measurement system and used Hofstede et al.'s (2010) cultural dimensions.

Finally, consistent with previous studies (Dewenter and Malatesta, 2001; Lo et al., 2014), labour intensity was measured as the ratio of the number of employees to total assets of the firm.

Two separate regression equations were used to avoid multi-collinearity issues (correlation matrix is reported in Table V):

$$
\begin{aligned}
& \text { Model 1:AP } k=\beta_{0}+\beta_{1}\left(P P_{k}\right)+\beta_{2}\left(F \text { Size }_{k}\right)+\beta_{3}\left(\text { Year }_{k}\right)+\beta_{4}(\text { ISO 9001 } k) \\
& +\beta_{5}\left(\text { ISO } 14001_{k}\right)+\beta_{6}(\text { OHSAS 18001 } k)+\beta_{7}\left(\text { ISize }_{k h}\right) \\
& +\beta_{8}\left(L I_{k}\right)+\beta_{9}\left(H D I_{k}\right)+e_{k}
\end{aligned}
$$




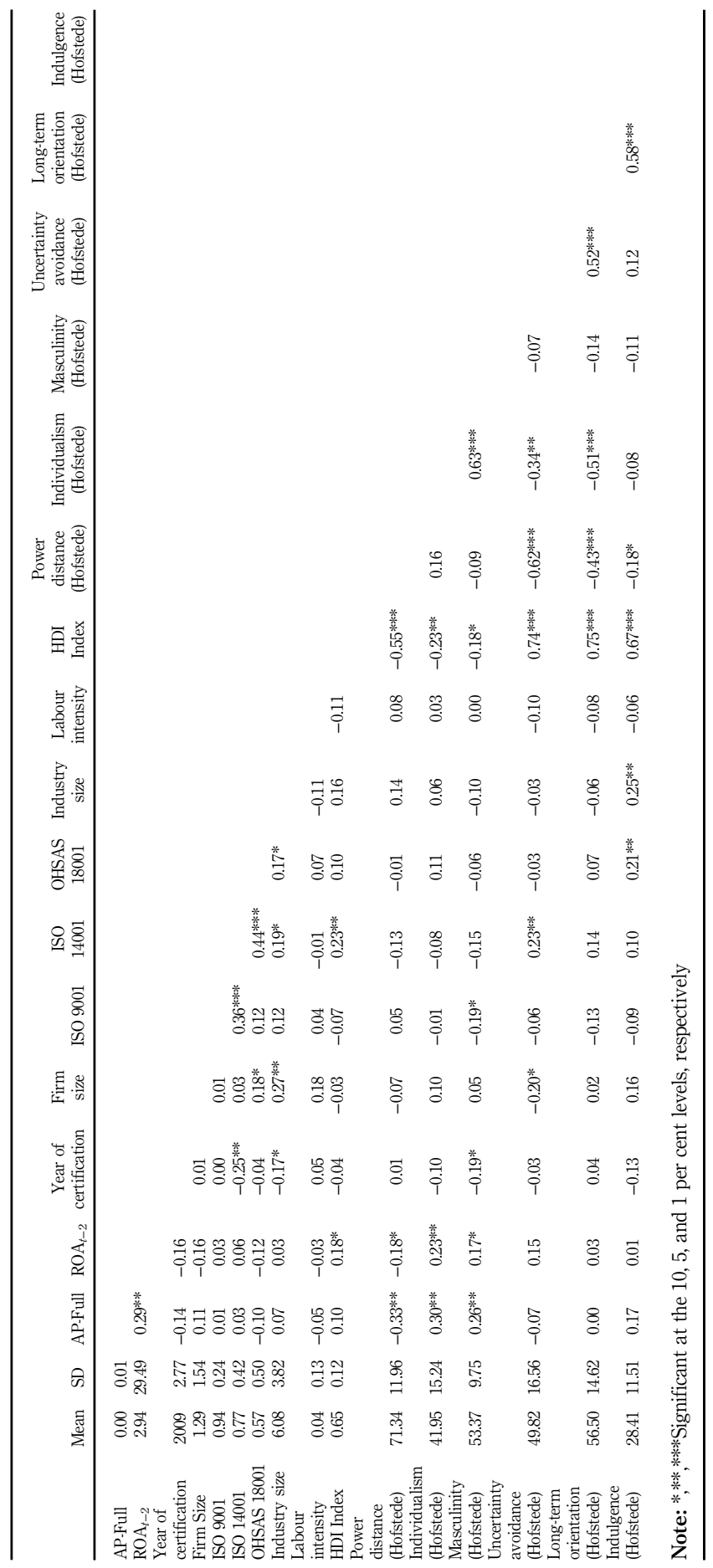

1641 certification 
IJOPM

37,11

1642
Model $2: A P_{k}=\beta_{0}+\beta_{1}\left(P P_{k}\right)+\beta_{2}\left(F\right.$ Size $\left._{k}\right)+\beta_{3}\left(\right.$ Year $\left._{k}\right)+\beta_{4}(I S O$ 9001 $)$

$$
\begin{aligned}
& +\beta_{5}\left(\text { ISO } 14001_{k}\right)+\beta_{6}\left(\text { OHSAS } 18001_{k}\right)+\beta_{7}\left(\text { ISize }_{k h}\right) \\
& +\beta_{8}\left(L_{k}\right)+\beta_{9}\left(H_{k 1}\right)+\beta_{10}\left(H_{k 2}\right)+\beta_{11}\left(H_{k 3}\right)+\beta_{12}\left(H_{k 4}\right) \\
& +\beta_{13}\left(H_{k 5}\right)+\beta_{14}\left(H_{k 6}\right)+e_{k}
\end{aligned}
$$

where $\mathrm{AP}_{k}$ is the abnormal performance of ROA of the $k$ th sampled firm in the period $t-2$ to $t+2, \mathrm{PP}_{k}$ is its ROA in the year $t-2, \mathrm{FSize}_{k}$ is the natural logarithm[2] of its number of employees in year $t-2$, year $_{k}$ is the year in which SA8000 certification is obtained (year $t$ ), ISO $9001_{k}$, ISO $14001_{k}$, and OHSAS $18001_{k}$ are dummy variables indicating whether the firm has these certifications, ISize $e_{k h}$ is the industry size measured as the mean number of employees of companies in the $h$ th sector of the firm, $\mathrm{LI}_{k}$ is the labour intensity of the firm, $\mathrm{HDI}_{k}$ is the Human Development Index of the country of origin of the firm, and $H_{k 1}-H_{k 6}$ are the Hofstede's cultural dimensions.

\section{Results}

Table VI summarises the results concerning the performance effects of SA8000 adoption, highlighting the abnormal performance of certified companies against the control firms in the event study period. As non-parametric tests have been argued to be more powerful than parametric ones (e.g. Barber and Lyon, 1996; De Jong et al., 2014), we consider the WRS or the sign test (in case of skewed distribution, absolute skewness $>1$ ) in testing our hypotheses. To take into account the multiple-testing problem, the false discovery rate methodology proposed by Benjamini and Hochberg (1995) was applied.

We find significant positive abnormal labour productivity performance of SA8000certified firms from year $t-1$ to $t+1$ and $t+2$ and from year $t$ to $t+1$ and $t+2$. $H 1$ is therefore supported. Certified firms also exhibit positive statistically significant abnormal sales performance from year $t-2$ to $t-1, t, t+1$, and $t+2$ ( $H 2$ is supported). Finally, no significant effect of SA8000 on profitability is observed in the event study period (H3 is not supported).

Table VII reports the results of OLS regressions performed to study the possible contingency factors moderating the relationship between SA8000 certification and profitability. The level of development of the country and the labour intensity of the company have no effect on this relationship ( $H 4 a$ and $H 5$ are rejected). A significant negative moderating effect is instead identified for two cultural dimensions, i.e., power distance and uncertainty avoidance, partially supporting $H 4 b$. In addition, the control variable OHSAS 18001 has a significant negative effect, suggesting that companies having this certification have fewer benefits of profitability from the adoption of SA8000 (this might reflect the fact that a lower degree of improvement is experienced by firms with higher initial performance, e.g. Park et al., 2010).

Figure 2 provides a summary of the research hypotheses tested by our study and highlights the ones empirically supported.

\section{Discussion}

The first result of our study is that SA8000 certification has a positive significant effect on labour productivity (H1). This provides empirical support for the extant literature which postulated that SA8000 implementation contributes to the increased satisfaction and enthusiasm of the employees (e.g. Rohitratana, 2002; Miles and Munilla, 2004; Ciliberti et al., 2011). It also sustains our hypothesis, grounded in agency theory, that SA8000 may mitigate both moral hazard and adverse selection problems between the firms (principals) and their employees (agents). 


\begin{tabular}{|c|c|c|c|c|c|c|c|}
\hline Period & AP mean & AP median & Skewness & $p$-value ( $t$-test) & $p$-value (WSR) & $p$-value (sign test) & . \\
\hline \multicolumn{8}{|c|}{ Labour productivity (operating income/number of employees) } \\
\hline$t-3$ to $t-2$ & 32.497 & 0.534 & $\times$ & 0.314 & 0.218 & 0.308 & \\
\hline$t-2$ to $t-1$ & -1.408 & -0.606 & $x$ & 0.296 & 0.064 & 0.106 & \\
\hline$t-2$ to $t$ & -3.350 & -0.542 & $x$ & 0.082 & 0.110 & 0.230 & \\
\hline$t-2$ to $t+1$ & 1.163 & 0.550 & & 0.581 & 0.297 & 0.141 & \\
\hline$t-2$ to $t+2$ & 2.037 & 1.031 & & 0.446 & 0.383 & 0.389 & 1643 \\
\hline$t-1$ to $t$ & -1.871 & 0.394 & & 0.191 & 0.755 & 0.326 & \\
\hline$t-1$ to $t+1$ & 2.913 & 1.212 & & 0,231 & $0.005^{* *}$ & $0.003 * *$ & \\
\hline$t-1$ to $t+2$ & 4.019 & 1.675 & & 0.086 & $0.012^{* * *}$ & $0.036^{*}$ & \\
\hline$t$ to $t+1$ & 4.227 & 1.420 & $x$ & 0.063 & $0.001^{* * *}$ & $0.009 * *$ & \\
\hline$t$ to $t+2$ & 6.172 & 2.588 & $x$ & $0.007^{*}$ & $0.000 * * * *$ & $0.000 * * *$ & \\
\hline$t+1$ to $t+2$ & 0.843 & 0.463 & & 0.731 & 0.550 & 0.712 & \\
\hline \multicolumn{8}{|c|}{ Sales performance (yearly percentage change in industrial sales) } \\
\hline$t-3$ to $t-2$ & -35.6351 & -1.9359 & $x$ & 0.062 & 0.097 & 0.762 & \\
\hline$t-2$ to $t-1$ & 58.0330 & 4.0796 & $\times$ & 0.235 & $0.002^{* * *}$ & $0.020^{*}$ & \\
\hline$t-2$ to $t$ & 14.3304 & 10.7109 & $x$ & $0.004^{* *}$ & $0.000 * * *$ & $0.001 * *$ & \\
\hline$t-2$ to $t+1$ & 15.1768 & 12.8258 & $x$ & $0.014^{*}$ & 0.000 *** & $0.017^{*}$ & \\
\hline$t-2$ to $t+2$ & 6.6751 & 6.8427 & & 0.036 & $0.014^{* * *}$ & 0.048 & \\
\hline$t-1$ to $t$ & -44.9953 & 3.7341 & $x$ & 0.368 & 0.467 & 0.185 & \\
\hline$t-1$ to $t+1$ & -49.7419 & 0.6204 & $x$ & 0.356 & 0.737 & 0.828 & \\
\hline$t-1$ to $t+2$ & -67.5717 & 0.1432 & $x$ & 0.305 & 0.823 & 1.000 & \\
\hline$t$ to $t+1$ & -2.1187 & -1.1003 & & 0.785 & 0.721 & 0.828 & \\
\hline$t$ to $t+2$ & -11.4892 & -12.6731 & $\times$ & 0.086 & $0.022 * *$ & $0.008^{* *}$ & \\
\hline$t+1$ to $t+2$ & -9.9836 & -3.7464 & $x$ & 0.142 & 0.287 & 0.131 & \\
\hline \multicolumn{8}{|c|}{ Profitability (return on assets) } \\
\hline$t-3$ to $t-2$ & -2.456 & -0.022 & $x$ & 0.326 & 0.031 & 0.012 & \\
\hline$t-2$ to $t-1$ & -0.072 & -0.001 & $x$ & 0.202 & 0.962 & 0.480 & \\
\hline$t-2$ to $t$ & -0.054 & 0.007 & $\times$ & 0.750 & 0.447 & 0.475 & \\
\hline$t-2$ to $t+1$ & 0.001 & 0.001 & $x$ & 0.993 & 0.627 & 0.743 & \\
\hline$t-2$ to $t+2$ & 0.085 & 0.001 & & 0.578 & 0.487 & 1.00 & \\
\hline$t-1$ to $t$ & 0.020 & 0.001 & $x$ & 0.913 & 0.303 & 0.759 & \\
\hline$t-1$ to $t+1$ & 0.069 & 0.011 & $x$ & 0.704 & 0.139 & 0.230 & \\
\hline$t-1$ to $t+2$ & 0.173 & 0.000 & $x$ & 0.328 & 0.168 & 1.00 & \\
\hline$t$ to $t+1$ & 0.022 & 0.005 & & 0.822 & 0.278 & 0.156 & \\
\hline$t$ to $t+2$ & 0.132 & 0.019 & $x$ & 0.639 & 0.152 & 0.349 & Abnormal \\
\hline$t+1$ to $t+2$ & 0.099 & 0.006 & & 0.730 & 0.263 & 0.160 & $\begin{array}{r}\text { Abnormal } \\
\text { performance in labour }\end{array}$ \\
\hline \multicolumn{8}{|c|}{ 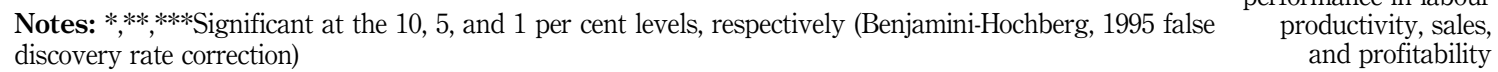 } \\
\hline
\end{tabular}

In addition, during the event study period SA8000-certified companies are shown to have better sales performance than non-certified firms similar in industry type, size, and pre-certification sales (in year $t-2$ ) (H2). The SA8000 signalling effect of the firm's commitment to CSR practices to major customers - that we postulated drawing from agency theory - allows certified companies to perform better than the comparable control firms. Instead, no significant effect of SA8000 on profitability is observed during the event study period. One possible explanation for this is that there is a time lag for profitability to catch up, i.e., the effect on profitability may take longer to be achieved than the effect on sales performance and may therefore need to be observed only examining longer periods (e.g. $t+3$, $t+4, t+5)$. De Jong et al. (2014) show, for instance, that the environmental certification ISO 14001 has only a long-term effect on profitability since the environmental capabilities facilitated by this certification take a long time to develop. 
IJOPM

37,11

Moderating factors

\begin{tabular}{lccc}
\hline & Model 0 & Model 1 (HDI) & Model 2 (Hofstede) \\
\hline ROA $_{t-2}$ & $0.277^{*}$ & $0.267^{*}$ & 0.081 \\
Firm size & 0.095 & 0.104 & -0.109 \\
Year of certification & -0.127 & -0.123 & 0.002 \\
ISO 9001 & 0.002 & 0.011 & 0.003 \\
ISO 14001 & 0.060 & 0.046 & 0.218 \\
OHSAS 18001 & -0.139 & -0.139 & $-0.340^{* *}$ \\
Industry size & -0.039 & -0.035 & 0.164 \\
Labour intensity & & -0.034 & 0.017 \\
HDI Index & & 0.011 & $-0.687^{* * * * *}$ \\
Power distance (Hofstede) & & 0.243 \\
Individualism (Hofstede) & & & 0.093 \\
Masculinity (Hofstede) & & & $-0.563^{* * * *}$ \\
Uncertainty avoidance (Hofstede) & & & 0.075 \\
Long-term orientation (Hofstede) & & 0.125 & 0.092 \\
Indulgence (Hofstede) & & 0.000 & 0.464 \\
$R^{2}$ & 0.124 & & 0.311 \\
Adjusted $R^{2}$ & 0.015 & &
\end{tabular}

Notes: Standardized regression coefficients are reported. *************Significant at the $10,5,1$, and 0.1 per cent levels, respectively
Figure 2.

Summary of the results

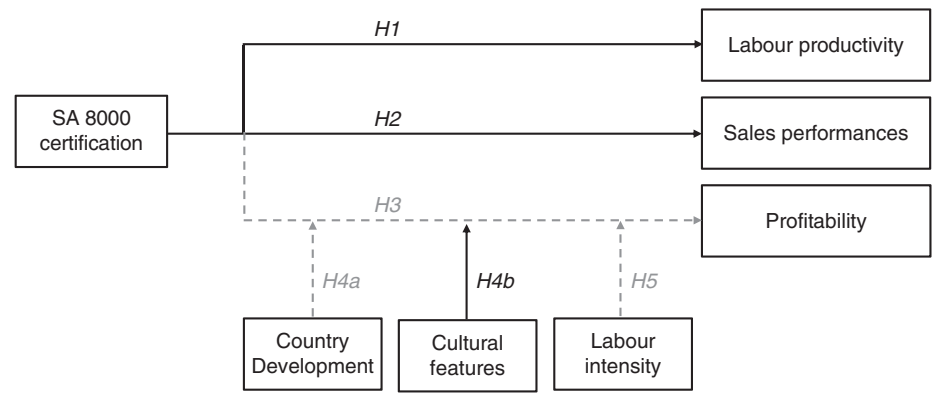

Our analyses further highlight that the relationship between SA8000 adoption and profitability is moderated by some country of origin cultural features. In more details, SA8000 certification has a stronger positive effect on profitability in companies headquartered in countries characterised by low power distances, i.e., where unequally distributed power is less accepted, and/or low uncertainty avoidance, i.e., where uncertainty and ambiguity are well tolerated and informality prevails over formality in interactions i.e., more risk taking rather than risk aversion (e.g. Malaysia and Vietnam) (Hofstede et al., 2010); rather, we do not find the moderating effects of other Hofstede's cultural dimensions and of the level of development of the country.

These findings are of particular relevance since, to the best of our knowledge, the moderating effect of national culture on the relationship between CSR practices and firm performance has not been studied previously. The result on power distance could be explained by a twofold reasoning. First, the SA8000 certification costs incurred for companies located in low power distance countries might be lower since employees are in general treated more equally and the gap to be filled to obtain the certification is relatively smaller (Sartor et al., 2016). Second, employees of companies located in low power distance countries might be more sensitive to the improvement in working environment (Ringov and Zollo, 2007). Similarly, assuming that the home country represents a significant sales 
market, customers with a low power distance culture might be more sensitive to working conditions issues. The result on uncertainty avoidance finds a justification in the different motivations for obtaining the certification and the different level of implementation, i.e., symbolic vs substantive (Christmann and Taylor, 2006). Companies located in countries characterised by high uncertainty avoidance i.e., that are risk-averse, adopt the certification mainly to reduce reputational risk and opt for symbolic implementation, i.e., aimed at formally obtaining the certification but not at changing the procedures, the management systems, and the working conditions (Christmann and Taylor, 2006). Companies located in countries characterised by low uncertainty avoidance, i.e., that are risk taking, adopt instead the certification to improve their performances, and opt for a substantive implementation which envisages an effective management system, health and safety monitoring activities, and periodic visits to suppliers. The effects of the certifications on profitability are therefore higher in companies located in countries characterised by low uncertainty avoidance.

The SA8000 certification shows positive effects (i.e. improving sales as well as labour productivity) already in the medium term (within three years after the obtainment). This could explain why long-term orientation does not moderate the relationship between SA8000 adoption and profitability. In addition, masculinity has not significant effect in our study as well as in many cross-cultural studies in supply chain management (Dong-Jin et al., 2001; Scheer et al., 2003).

Finally, the insignificant moderating effect of the level of development of the country of origin could be explained in a twofold reason. First, while the performance impact of the SA8000 certification are higher in developing countries, certification costs are also higher, leading to a zero sum effects. Second, recent studies have questioned the recognisability of national influences in the adoption of management practices, arguing that the growing interdependence between world economies and increasing mobility tend to flatten work practices and the national models (e.g. Schonberger, 2007; Rodrik, 2013).

\section{Conclusions}

Contribution to theory

Our paper contributes to operations and supply chain management theory in at least three significant ways. First, extant theories - in particular agency theory - postulate a positive effect of SA8000 certification on firm performance, drawing from the following arguments: SA8000 adoption contributes to reduce the information asymmetry between the (top) management and the employees, this way mitigating the moral hazard and adverse selection problems and SA8000 acts as a credible signal for the customers of the firm's commitment to CSR practices (e.g. Ciliberti et al., 2011). Our study is the first one that rigorously and empirically tests the effects of the ethical certification SA8000 on firm performance with a cross-country sample. In particular, we found a positive effect of SA8000 adoption on labour productivity and sales performance. This represents a significant advancement in a research field, which is characterised by mostly conceptual and case-based research and is expected to grow considerably (Llach et al., 2015). Second, we contribute to the wider debate on the effects of CSR practices on firm performance by supporting the social impact school which postulates that CSR enhances the firm's reputation among stakeholders and leads to better performance (e.g. Preston and O'Bannon, 1997; Berman et al., 1999; Carmeli et al., 2007). We showed in fact based on reliable objective balance sheet data that CSR practices significantly affect labour productivity and sales performance. The relationship between SA8000 and profitability was instead not confirmed by our study. A first explanation that can be drawn from previous literature is that the benefits of the certification do not compensate the cost incurred for the adoption and management. There are however in our view significant rooms for conceptual/theoretical development in this field as well as for empirical analyses. Third, we shed light on the 
IJOPM

37,11

1646

moderating effect of certain cultural features (i.e. power distance and uncertainty avoidance) on the relationship between SA8000 adoption and firm performance. On the one hand, this represents the first attempt to apply contingency theory to SA8000 certification. On the other hand, previous CSR studies based on contingency theory did not consider cultural features. We are therefore among the first to shed light on this contingent factor, which is of particular importance considering the nature of CSR practices (i.e. conceptually depending on human/ cultural issues). This aforementioned result may also suggest the need to adapt CSR practices to the countries where they are implemented and call for future comparative studies.

\section{Contribution to practice and society}

The choice of the CSR practices/standards to be adopted (if convenient) is strategic for managers, considering the (idiosyncratic) investments required and the potential positive and negative performance implications. Our paper helps managers in their decision-making process by providing a systematic review of all the possible effects of SA8000 (the most important ethical certification standard) adoption on firm performances; empirically testing some effects, i.e., increasing labour productivity, increasing sales performance; empirically showing that the aforementioned effects are not affected by firm size, year of certification, industry size, labour intensity of the company, or level of development of the company's home country. Managers could use the evidence to justify the cost incurred for SA8000 adoption to the shareholders.

Our study has also significant implications for regulatory bodies such as SAI and International Standard Organization (ISO). SAI could use our findings to further strengthen SA8000 certification and orientate the implementation practices. For instances, our finding that the relationship between SA8000 adoption and profitability is moderated by cultural features might suggest to SAI a country-specific approach to the certification. ISO could draw from our analyses some suggestions for further refining its ISO 26000 process standard (i.e. a set of CSR guidelines).

Finally, by empirically proving the positive effects of SA8000 certification, our study might also potentially contribute to the diffusion of the SA8000 certification and more generally of CSR standards. This might potentially contribute towards a more sustainable society, in which people's needs and comfort and environmental safeguards are considered by companies as top priorities along with economic profits.

\section{Limitations and future research}

The results of our study should be viewed in the light of some limitations. First, we used secondary data from the Compustat database. This imposed some restrictions in the analysed sample, consisting of (large) listed firms, and in the considered research hypotheses, i.e., only focussed on performances that could be calculated from balance sheet data. Second, our event study period ranged from $t-2$ to $t+2$. This did not allow us to test whether the SA8000 certification has positive effects in the longer run (e.g. $t+3, t+4, t+5$ ). Third, balance sheet data at year $t+2$ and/or $t+1$ were not available for firms which obtained the certification in 2013 (ten firms) and 2014 (two firms) slightly reducing the dimension of the sample for these specific analyses. Fourth, our study only included SA8000 certification, neglecting other CSR practices and standards.

Future research is needed to overcome the aforementioned limitations and more generally to shed further light on the effects of SA8000 certifications and other CSR practices/standards on firm performances. Researchers could, for instance, employ survey methods to empirically test the performance implications of SA8000 hypothesised by previous studies and summarised in Table I on wider and more heterogeneous samples (e.g. including listed and non-listed firms, including large and small firms). This might allow them: to test all the effects hypothesised by previous studies together; to consider a wider 
time horizon; and to consider further moderators and control variables that were not available in this study (e.g. ethical leadership, see Zhu et al., 2014). In addition, the various components of the broad concept of profitability $(H 3)$ should be further broken down to better explain the results of our study. Finally, another direction for future research with significant implications for managers and regulatory bodies concerns a comparative analysis of the performance impact of different CSR practices and standards.

\section{Notes}

1. The analysed sample consists therefore of 101 certified firms and of a wide set of control firms (on average of eight for each certified firm).

2. Natural logarithms were used to normalise the distribution.

\section{References}

Annunziata, A., Ianuario, S. and Pascale, P. (2011), “Consumers' attitudes toward labelling of ethical products: the case of organic and fair trade products", Journal of Food Products Marketing, Vol. 17 No. 5, pp. 518-535.

Balakrishnan, S. and Koza, M.P. (1993), "Information asymmetry, adverse selection and joint-ventures: theory and evidence", Journal of Economic Behaviour and Organization, Vol. 20 No. 1, pp. 99-117.

Barber, B.M. and Lyon, J.D. (1996), "Detecting abnormal operating performance: the empirical power and specification of test statistics", Journal of Financial Economics, Vol. 41 No. 3, pp. 359-399.

Barnett, M.L. and Salomon, R.M. (2006), "Beyond dichotomy: the curvilinear relationship between social responsibility and financial performance”, Strategic Management Journal, Vol. 27 No. 11, pp. 1101-1122.

Battaglia, M., Testa, F., Bianchi, L., Iraldo, F. and Frey, M. (2014), “Corporate social responsibility and competitiveness within SMEs of the fashion industry: evidence from Italy and France", Sustainability, Vol. 6 No. 2, pp. 872-893.

Becchetti, L., Ciciretti, R. and Hasan, I. (2007), "Corporate social responsibility and shareholder's value: an event study analysis", Working Paper No. 2007-6, Federal Reserve Bank of Atlanta, available at: www.econstor.eu/bitstream/10419/70692/1/572361998.pdf

Benjamini, Y. and Hochberg, Y. (1995), "Controlling the false discovery rate: a practical and powerful approach to multiple testing", Journal of the Royal Statistical Society, Vol. 57 No. 1, pp. 289-300.

Berman, S.L., Wicks, A.C., Kotha, S. and Jones, T.M. (1999), "Does stakeholder orientation matter? The relationship between stakeholder management models and firm financial performance", Academy of Management Journal, Vol. 42 No. 5, pp. 488-506.

Beschorner, T. and Müller, M. (2007), "Social standards: toward an active ethical involvement of businesses in developing countries", Journal of Business Ethics, Vol. 73 No. 1, pp. 11-20.

Beske, P., Koplin, J. and Seuring, S. (2008), "The use of environmental and social standards by German first-tier suppliers of the Volkswagen AG", Corporate Social Responsibility and Environmental Management, Vol. 15 No. 2, pp. 63-75.

Brammer, S., Brooks, C. and Pavelin, S. (2006), "Corporate social performance and stock returns: UK evidence from disaggregate measures”, Financial Management, Vol. 35 No. 3, pp. 97-116.

Brammer, S. and Millington, A. (2008), "Does it pay to be different? An analysis of the relationship between corporate social and financial performance", Strategic Management Journal, Vol. 29 No. 12 , pp. $1325-1343$.

Cagliano, R., Caniato, F., Golini, R., Longoni, A. and Micelotta, E. (2011), “The impact of country culture on the adoption of new forms of work organization", International Journal of Operations and Production Management, Vol. 31 No. 3, pp. 297-323. 
IJOPM

37,11

Carmeli, A., Gilat, G. and Waldman, D.A. (2007), "The role of perceived organizational performance in organizational identification, adjustment and job performance", Journal of Management Studies, Vol. 44 No. 6, pp. 972-992.

Carroll, A.B. and Shabana, K.M. (2010), "The business case for corporate social responsibility: a review of concepts, research and practice", International Journal of Management Reviews, Vol. 12 No. 1, pp. 85-105.

Carter, C.R. and Rogers, D.S. (2008), "A framework of sustainable supply chain management: moving toward new theory", International Journal of Physical Distribution and Logistics Management, Vol. 38 No. 5, pp. 360-387.

Castka, P. and Balzarova, M.A. (2008), "ISO 26000 and supply chains - on the diffusion of the social responsibility standard", International Journal of Production Economics, Vol. 111 No. 2, pp. 274-286.

Choi, J.S., Kwak, Y.M. and Choe, C. (2010), "Corporate social responsibility and corporate financial performance: evidence from Korea”, Australian Journal of Management, Vol. 35 No. 3, pp. 291-311.

Christmann, P. and Taylor, G. (2006), "Firm self-regulation through international certifiable standards: determinants of symbolic versus substantive implementation”, Journal of International Business Studies, Vol. 37 No. 6, pp. 863-878.

Ciliberti, F., Pontrandolfo, P. and Scozzi, B. (2008), "Logistics social responsibility: Standard adoption and practices in Italian companies", International Journal of Production Economics, Vol. 113 No. 1 , pp. 88-106.

Ciliberti, F., de Groot, G., de Haan, J. and Pontrandolfo, P. (2009), "Codes to coordinate supply chains: SMEs' experiences with SA8000”, Supply Chain Management: An International Journal, Vol. 14 No. 2, pp. 117-127.

Ciliberti, F., de Haan, J., de Groot, G. and Pontrandolfo, P. (2011), "CSR codes and the principal-agent problem in supply chains: four case studies", Journal of Cleaner Production, Vol. 19 No. 8, pp. 885-894.

Coase, R.H. (1937), "The nature of the firm”, Economica, Vol. 4 No. 16, pp. 386-405.

Collison, D.J., Cobb, G., Power, D.M. and Stevenson, L.A. (2008), "The financial performance of the FTSE4Good indices", Corporate Social Responsibility and Environmental Management, Vol. 15 No. 1, pp. 14-28.

Corbett, C.J., Montes-Sancho, M.J. and Kirsch, D.A. (2005), "The financial impact of ISO 9000 certification in the United States: an empirical analysis", Management Science, Vol. 51 No. 7, pp. 1046-1059.

Crals, E. and Vereeck, L. (2005), "The affordability of sustainable entrepreneurship certification for SMEs", International Journal of Sustainable Development and World Ecology, Vol. 12 No. 2, pp. 173-184.

Crifo, P., Diaye, M.A. and Pekovic, S. (2016), “CSR-related management practices and firm performance: an empirical analysis of the quantity-quality trade-off on French data", International Journal of Production Economics, Vol. 171 No. 3, pp. 405-416, doi: 10.1016/j.jpe.2014.12.019.

De Jong, P., Paulraj, A. and Blome, C. (2014), “The financial impact of ISO 14001 certification: top-line, bottom-line or both?”, Journal of Business Ethics, Vol. 119 No. 1, pp. 131-149.

De Magistris, T., Del Giudice, T. and Verneau, F. (2015), "The effect of information on willingness to pay for canned tuna fish with different corporate social responsibility (CSR) certification: a pilot study", Journal of Consumer Affairs, Vol. 49 No. 2, pp. 457-471.

Dewenter, K.L. and Malatesta, P.H. (2001), "State-owned and privately-owned firms: an empirical analysis of profitability, leverage, and labor intensity", The American Economic Review, Vol. 91 No. 1, pp. 320-334.

Donaldson, L. (2001), The Contingency Theory of Organizations, Sage Publications, Thousand Oaks, CA.

Donaldson, T. and Preston, L.E. (1995), "The stakeholder theory of the corporation: concepts, evidence, and implications", Academy of Management Review, Vol. 20 No. 1, pp. 65-91. 
Dong-Jin, L., Jae, H.P. and Wong, Y.H. (2001), "A model of close business relationships in China (Guanxi)”, European Journal of Marketing, Vol. 35 Nos 1/2, pp. 51-69.

Eurostat (2014), "Business demography", available at: http://ec.europa.eu/eurostat/web/structuralbusiness-statistics/entrepreneurship/business-demography?p_p_id=NavTreeportletprod_ WAR_NavTreeportletprod_INSTANCE_98P2XZ2YW9tR\&p_p_lifecycle=0\&p_p_state= normal\&p_p_mode $=$ view\&p_p_col_id=column-2\&p_p_col_pos $=1 \&$ p_p_col_count $=2$ (accessed 31 January 2017).

Fernández Sánchez, J.L., Luna Sotorrío, L. and Baraibar Diez, E. (2015), “The relationship between corporate social responsibility and corporate reputation in a turbulent environment: Spanish evidence of the Ibex35 firms", Corporate Governance, Vol. 15 No. 4, pp. 563-575.

Foote, J., Gaffney, N. and Evans, J.R. (2010), "Corporate social responsibility: implications for performance excellence”, Total Quality Management, Vol. 21 No. 8, pp. 799-812.

Freeman, R.E. (1984), Strategic Management: A Stakeholder Approach, Pitman, Boston, MA.

Fuentes-García, F.J., Núñez-Tabales, J.M. and Veroz-Herradón, R. (2008), “Applicability of corporate social responsibility to human resources management: perspective from Spain", Journal of Business Ethics, Vol. 82 No. 1, pp. 27-44.

Gilbert, D.U. and Rasche, A. (2007), "Discourse ethics and social accountability: the ethics of SA8000", Business Ethics Quarterly, Vol. 17 No. 2, pp. 187-216.

Gilbert, D.U. and Rasche, A. (2008), "Opportunities and problems of standardized ethics initiatives a stakeholder theory perspective", Journal of Business Ethics, Vol. 82 No. 3, pp. 755-773.

Gilbert, D.U., Rasche, A. and Waddock, S. (2010), "Accountability in a global economy: the emergence of international accountability standards", Business Ethics Quarterly, Vol. 21 No. 1, pp. 23-44.

Godfrey, P.C., Merrill, C.B. and Hansen, J.M. (2009), "The relationship between corporate social responsibility and shareholder value: an empirical test of the risk management hypothesis", Strategic Management Journal, Vol. 30 No. 4, pp. 425-445.

Hendricks, K.B. and Singhal, V.R. (2008), "The effect of product introduction delays on operating performance", Management Science, Vol. 54 No. 5, pp. 878-892.

Henkle, D. (2005), "Gap Inc. sees supplier ownership of compliance with workplace standards as an essential element of socially responsible sourcing", Journal of Organizational Excellence, Vol. 25 No. 1, pp. 17-25.

Hofstede, G. (1980), Culture's Consequences: National Differences in Thinking and Organizing, Sage Publications, Beverly Hills, CA.

Hofstede, G., Hofstede, G.J. and Minkov, M. (2010), Cultures and Organizations: Software of the Mind: Intercultural Cooperation and its Importance for Survival, McGraw-Hill, New York, NY.

Hou, M., Liu, H., Fan, P. and Wei, Z. (2016), "Does CSR practice pay off in East Asian firms? A meta-analytic investigation”, Asia Pacific Journal of Management, Vol. 33 No. 1, pp. 195-228.

House, R.J., Hanges, P.J., Javidan, M., Dorfman, P.W. and Vipin, G. (2004), Culture, Leadership, and Organizations: The GLOBE Study of 62 Societies, Sage, Thousand Oaks, CA.

International Monetary Fund (2016), "World Economic Outlook", available at www.imf.org/external/ pubs/ft/weo/2016/01/index.htm (accessed 24 June 2016).

Jensen, M.C. and Meckling, W.H. (1976), "Theory of the firm: managerial behavior, agency costs and ownership structure”, Journal of Financial Economics, Vol. 3 No. 4, pp. 305-360.

Jia, F. and Lamming, R. (2013), "Cultural adaptation in Chinese-western supply chain partnerships: dyadic learning in an international context", International Journal of Operations \& Production Management, Vol. 33 No. 5, pp. 528-561.

Kang, H.H. and Liu, S.B. (2014), "Corporate social responsibility and corporate performance: a quantile regression approach", Quality and Quantity, Vol. 48 No. 6, pp. 3311-3325.

Khanna, M., Koss, P., Jones, C. and Ervin, D. (2007), "Motivations for voluntary environmental management”, Policy Studies Journal, Vol. 35 No. 4, pp. 751-772. 
IJOPM

37,11

Klassen, R.D. and Vereecke, A. (2012), "Social issues in supply chains: capabilities link responsibility, risk (opportunity), and performance", International Journal of Production Economics, Vol. 140 No. 1, pp. 103-115.

Koerber, C.P. (2010), "Corporate responsibility standards: current implications and future possibilities for peace through commerce", Journal of Business Ethics, Vol. 89 No. 4, pp. 461-480.

Koplin, J., Seuring, S. and Mesterharm, M. (2007), "Incorporating sustainability into supply management in the automotive industry - the case of the Volkswagen AG", Journal of Cleaner Production, Vol. 15 No. 11, pp. 1053-1062.

Lee, S., Seo, K. and Sharma, A. (2013), "Corporate social responsibility and firm performance in the airline industry: the moderating role of oil prices", Tourism Management, Vol. 38, pp. 20-30.

Lee, S., Singal, M. and Kang, K.H. (2013), "The corporate social responsibility - financial performance link in the US restaurant industry: do economic conditions matter?", International Journal of Hospitality Management, Vol. 32, pp. 2-10.

Llach, J., Marimon, F. and del Mar Alonso-Almeida, M. (2015), "Social Accountability 8000 standard certification: analysis of worldwide diffusion", Journal of Cleaner Production, Vol. 93, pp. 288-298.

Lo, C.K.Y., Pagell, M., Fan, D., Wiengarten, F. and Yeung, A.C.L. (2014), "OHSAS 18001 certification and operating performance: the role of complexity and coupling", Journal of Operation Management, Vol. 32 No. 5, pp. 268-280.

Lo, C.K.Y., Wiengarten, F., Humphreys, P., Yeung, A.C.L. and Cheng, T.C.E. (2013), "The impact of contextual factors on the efficacy of ISO 9000 adoption", Journal of Operation Management, Vol. 31 No. 5, pp. 229-235.

Longoni, A., Golini, R. and Cagliano, R. (2014), "The role of new forms of work organization in developing sustainability strategies in operations", International Journal of Production Economics, Vol. 147, Part A, pp. 147-160.

Margolis, J.D. and Walsh, J.P. (2003), "Misery loves companies: rethinking social initiatives by business", Administrative Science Quarterly, Vol. 48 No. 2, pp. 268-305.

Meehan, J., Meehan, K. and Richards, A. (2006), "Corporate social responsibility: the 3C-SR model”, International Journal of Social Economics, Vol. 33 Nos 5/6, pp. 386-398.

Merli, R., Preziosi, M. and Massa, I. (2015), "Social values and sustainability: a survey on drivers, barriers and benefits of SA8000 certification in Italian firms", Sustainability, Vol. 7 No. 4, pp. 4120-4130.

Miles, M.P. and Munilla, L.S. (2004), "The potential impact of social accountability certification on marketing: a short note", Journal of Business Ethics, Vol. 50 No. 1, pp. 1-11.

Miles, M.P., Munilla, L.S. and Darroch, J. (2006), "The role of strategic conversations with stakeholders in the formation of corporate social responsibility strategy", Journal of Business Ethics, Vol. 69 No. 2, pp. 195-205.

Ministry of Corporate Affairs (2015), "1st annual report", p. 32, available at: http://mca.gov.in/Ministry/ pdf/1AR2013_Eng.pdf (accessed 21 June 2016).

Mishra, S. and Suar, D. (2010), "Does corporate social responsibility influence firm performance of Indian companies?", Journal of Business Ethics, Vol. 95 No. 4, pp. 571-601.

Nishitani, K. (2010), "Demand for ISO 14001 adoption in the global supply chain: an empirical analysis focusing on environmentally-conscious markets", Resource and Energy Economics, Vol. 32 No. 3, pp. 395-407.

Orlitzky, M., Schmidt, F.L. and Rynes, S.L. (2003), "Corporate social and financial performance: a meta-analysis", Organization Studies, Vol. 24 No. 3, pp. 403-441.

Park, J.E., Kim, J., Dubinsky, A.J. and Lee, H. (2010), "How does sales force automation influence relationship quality and performance? The mediating roles of learning and selling behaviors", Industrial Marketing Management, Vol. 39 No. 7, pp. 1128-1138. 
Park, S.Y. and Lee, S. (2009), "Financial rewards for social responsibility a mixed picture for restaurant companies”, Cornell Hospitality Quarterly, Vol. 50 No. 2, pp. 168-179.

Prater, E., Biehl, M. and Smith, M.A. (2001), "International supply chain agility-tradeoffs between flexibility and uncertainty", International Journal of Operations \& Production Management, Vol. 21 Nos 5/6, pp. 823-839.

Preston, L.E. and O’Bannon, D.P. (1997), "The corporate social-financial performance relationship", Business and Society, Vol. 36 No. 4, pp. 419-429.

Qi, G., Zeng, S., Yin, H. and Lin, H. (2013), "ISO and OHSAS certifications: how stakeholders affect corporate decisions on sustainability", Management Decision, Vol. 51 No. 10, pp. 1983-2005.

Rasche, A. (2009), "Toward a model to compare and analyze accountability standards - the case of the UN Global Compact", Corporate Social Responsibility and Environmental Management, Vol. 16 No. 4, pp. 192-205.

Rasche, A. (2010a), "The limits of corporate responsibility standards", Business Ethics: A European Review, Vol. 19 No. 3, pp. 280-291.

Rasche, A. (2010b), “Collaborative Governance 2.0”, Corporate Governance, Vol. 10 No. 4, pp. 500-511.

Rasche, A. and Esser, D.E. (2006), "From stakeholder management to stakeholder accountability", Journal of Business Ethics, Vol. 65 No. 3, pp. 251-267.

Renneboog, L., Ter Horst, J. and Zhang, C. (2008), "Socially responsible investments: Institutional aspects, performance, and investor behaviour", Journal of Banking \& Finance, Vol. 32 No. 9, pp. 1723-1742.

Reynolds, M. and Yuthas, K. (2008), "Moral discourse and corporate social responsibility reporting", Journal of Business Ethics, Vol. 78 Nos 1/2, pp. 47-64.

Ringov, D. and Zollo, M. (2007), "The impact of national culture on corporate social performance", Corporate Governance: The International Journal of Business in Society, Vol. 7 No. 4, pp. 476-485.

Rodrik, D. (2013), "Unconditional convergence in manufacturing", The Quarterly Journal of Economics, Vol. 128 No. 1, pp. 165-204.

Rohitratana, K. (2002), "SA 8000: a tool to improve quality of life", Managerial Auditing Journal, Vol. 17 Nos $1 / 2$, pp. 60-64.

Ruževičius, J. and Serafinas, D. (2007), “The development of socially responsible business in Lithuania”, Engineering Economics, Vol. 1 No. 51, pp. 36-43.

Salomone, R. (2008), "Integrated management systems: experiences in Italian organizations", Journal of Cleaner Production, Vol. 16 No. 16, pp. 1786-1806.

Sartor, M., Orzes, G., Di Mauro, C., Ebrahimpour, M. and Nassimbeni, G. (2016), “The SA8000 social certification standard: literature review and theory-based research agenda", International Journal of Production Economics, Vol. 175, pp. 164-181.

Scheer, L.K., Kumar, N. and Steenkamp, J.-B.E.M. (2003), "Reactions to perceived inequity in US and Dutch inter-organizational relationships", Academy of Management Journal, Vol. 46 No. 3, pp. 303-316.

Schonberger, R.J. (2007), "Japanese production management: an evolution - with mixed success", Journal of Operations Management, Vol. 25 No. 2, pp. 403-419.

Shen, C.H. and Chang, Y. (2009), "Ambition versus conscience, does corporate social responsibility pay off? The application of matching methods", Journal of Business Ethics, Vol. 88 No. 1, pp. 133-153.

Smith, P.B. (1992), "Organizational behaviour and national cultures", British Journal of Management, Vol. 3 No. 1, pp. 39-51.

Social Accountability Accreditation Services (SAAS) (2014), "Certified facilities list”, available at: www. saasaccreditation.org/certfacilitieslist.htm (accessed 10 January 2014).

Social Accountability International (SAI) (2014), "SA8000 Standard”, available at: http://www.sa-intl.org/ index.cfm?fuseaction=page.viewPage\&pageID=1689\&parentID=4 (accessed 8 February 2015). 
IJOPM

37,11

1652

Stigzelius, I. and Mark-Herbert, C. (2009), "Tailoring corporate responsibility to suppliers: managing SA8000 in Indian garment manufacturing", Scandinavian Journal of Management, Vol. 25 No. 1, pp. 46-56.

Suchman, M.C. (1995), "Managing legitimacy: strategic and institutional approaches", Academy of Management Review, Vol. 20 No. 3, pp. 571-610.

Surroca, J.J.A., Tribó, S. and Waddock (2010), "Corporate responsibility and financial performance: the role of intangible resources", Strategic Management Journal, Vol. 31 No. 5, pp. 463-490.

Swink, M. and Jacobs, B.W. (2012), "Six Sigma adoption: operating performance impacts and contextual drivers of success", Journal of Operations Management, Vol. 30 No. 6, pp. 437-453.

Takahashi, T. and Nakamura, M. (2010), "The impact of operational characteristics on firms' EMS decisions: strategic adoption of ISO 14001 certifications", Corporate Social Responsibility and Environmental Management, Vol. 17 No. 4, pp. 215-229.

Tang, Z., Hull, C.E. and Rothenberg, S. (2012), "How corporate social responsibility engagement strategy moderates the CSR-financial performance relationship", Journal of Management Studies, Vol. 49 No. 7, pp. 1274-1303.

Tate, W.L., Ellram, L.M. and Kirchoff, J.F. (2010), "Corporate social responsibility reports: a thematic analysis related to supply chain management", Journal of Supply Chain Management, Vol. 46 No. 1, pp. 19-44.

Tencati, A. and Zsolnai, L. (2009), "The collaborative enterprise”, Journal of Business Ethics, Vol. 85 No. 3, pp. 367-376.

Unioncamere (2015), "Movimprese", available at: www.infocamere.it/movimprese/-/asset_publisher/ ueRnd4KL4Z0I/content/dati-totali-imprese-1995-2015?inheritRedirect=false\&redirect=http $\% 3 \mathrm{~A} \%$ 2F\%2Fwww.infocamere.it\%2Fmovimprese \%3Fp_p_id\%3D101_INSTANCE_ueRnd4KL4Z0I\% 26p_p_lifecycle $\% 3 D 0 \% 26$ p_p_state $\% 3$ Dnormal $\% 26$ p_p_mode $\% 3$ Dview $\% 26$ p_p_col_id $\%$ 3Dcolumn-1\%26p_p_col_pos\%3D1\%26p_p_col_count\%3D2 (accessed 21 June 2016).

United Nations Development Programme ( (2014), "Human Development Report", available at: www.undp.org/content/dam/undp/library/corporate/HDR/2014HDR/HDR-2014-English.pdf (accessed 20 January 2014).

Valmohammadi, C. (2014), "Impact of corporate social responsibility practices on or ganizational performance: an ISO 26000 perspective", Social Responsibility Journal, Vol. 10 No. 3, pp. 455-479.

Wang, H. (2008), "The influence of SA8000 standard on the export trade of China”, Asian Social Science, Vol. 4 No. 1, pp. 116-119.

Wang, H. and Choi, J. (2013), "A new look at the corporate social-financial performance relationship the moderating roles of temporal and inter-domain consistency in corporate social performance", Journal of Management, Vol. 39 No. 2, pp. 416-441.

Wang, H., Choi, J. and Li, J. (2008), “Too little or too much? Untangling the relationship between corporate philanthropy and firm financial performance", Organization Science, Vol. 19 No. 1, pp. 143-159.

Werre, M. (2003), "Implementing corporate responsibility - the Chiquita case", Journal of Business Ethics, Vol. 44 Nos 2/3, pp. 247-260.

Wiengarten, F., Gimenez, C., Fynes, B. and Ferdows, K. (2015), "Exploring the importance of cultural collectivism on the efficacy of lean practices: taking an organisational and national perspective", International Journal of Operations and Production Management, Vol. 35 No. 3, pp. 370-391.

Williamson, O.E. (1975), Markets and Hierarchies, The Free Press, New York, NY.

Williamson, O.E. (1996), The Mechanisms of Governance, Oxford University Press, New York, NY.

Wu, M.W. and Shen, C.H. (2013), "Corporate social responsibility in the banking industry: motives and financial performance”, Journal of Banking \& Finance, Vol. 37 No. 9, pp. 3529-3547.

Youn, H., Hua, N. and Lee, S. (2015), "Does size matter? Corporate social responsibility and firm performance in the restaurant industry", International Journal of Hospitality Management, Vol. 51, pp. 127-134. 
Zhao, Z.Y., Zhao, X.J., Davidson, K. and Zuo, J. (2012), "A corporate social responsibility indicator system for construction enterprises", Journal of Cleaner Production, Vols 29-30, pp. 277-289.

Zhu, Y., Sun, L.Y. and Leung, A.S. (2014), "Corporate social responsibility, firm reputation, and firm performance: the role of ethical leadership", Asia Pacific Journal of Management, Vol. 31 No. 4, pp. 925-947.

Zutshi, A., Creed, A. and Sohal, A. (2009), "Child labour and supply chain: profitability or (mis) management”, European Business Review, Vol. 21 No. 1, pp. 42-63.

\section{Further reading}

Beske, P., Koplin, J. and Seuring, S. (2006), "The use of environmental and social standards by German first-tier suppliers of the Volkswagen AG”, Corporate Social Responsibility and Environmental Management, Vol. 15 No. 2, pp. 63-75.

Castka, P. and Balzarova, M.A. (2007), "A critical look on quality through CSR lenses: key challenges stemming from the development of ISO 26000", International Journal of Quality and Reliability Management, Vol. 24 No. 7, pp. 738-752.

Chicksand, D., Watson, G., Walker, H., Radnor, Z. and Johnston, R. (2012), "Theoretical perspectives in purchasing and supply chain management: an analysis of the literature", Supply Chain Management: An International Journal, Vol. 17 No. 4, pp. 454-472.

Karapetrovic, S. and Casadesús, M. (2009), "Implementing environmental with other standardized management systems: scope, sequence, time and integration", Journal of Cleaner Production, Vol. 17 No. 5, pp. 533-540.

Robinson, P.K. (2010), "Responsible retailing: the practice of CSR in banana plantations in Costa Rica", Journal of Business Ethics, Vol. 91 No. 2, pp. 279-289.

Tsai, W.-H. and Chou, W.-C. (2009), "Selecting management systems for sustainable development in SMEs: a novel hybrid model based on DEMATEL, ANP, and ZOGP", Expert Systems with Applications, Vol. 36 No. 2, pp. 1444-1458.

\section{Corresponding author}

Fu Jia can be contacted at: Fu.Jia@exeter.ac.uk

For instructions on how to order reprints of this article, please visit our website: 